\title{
norden
}

\section{Future EU energy and climate regulation}

Implications for Nordic energy development and Nordic stakeholders

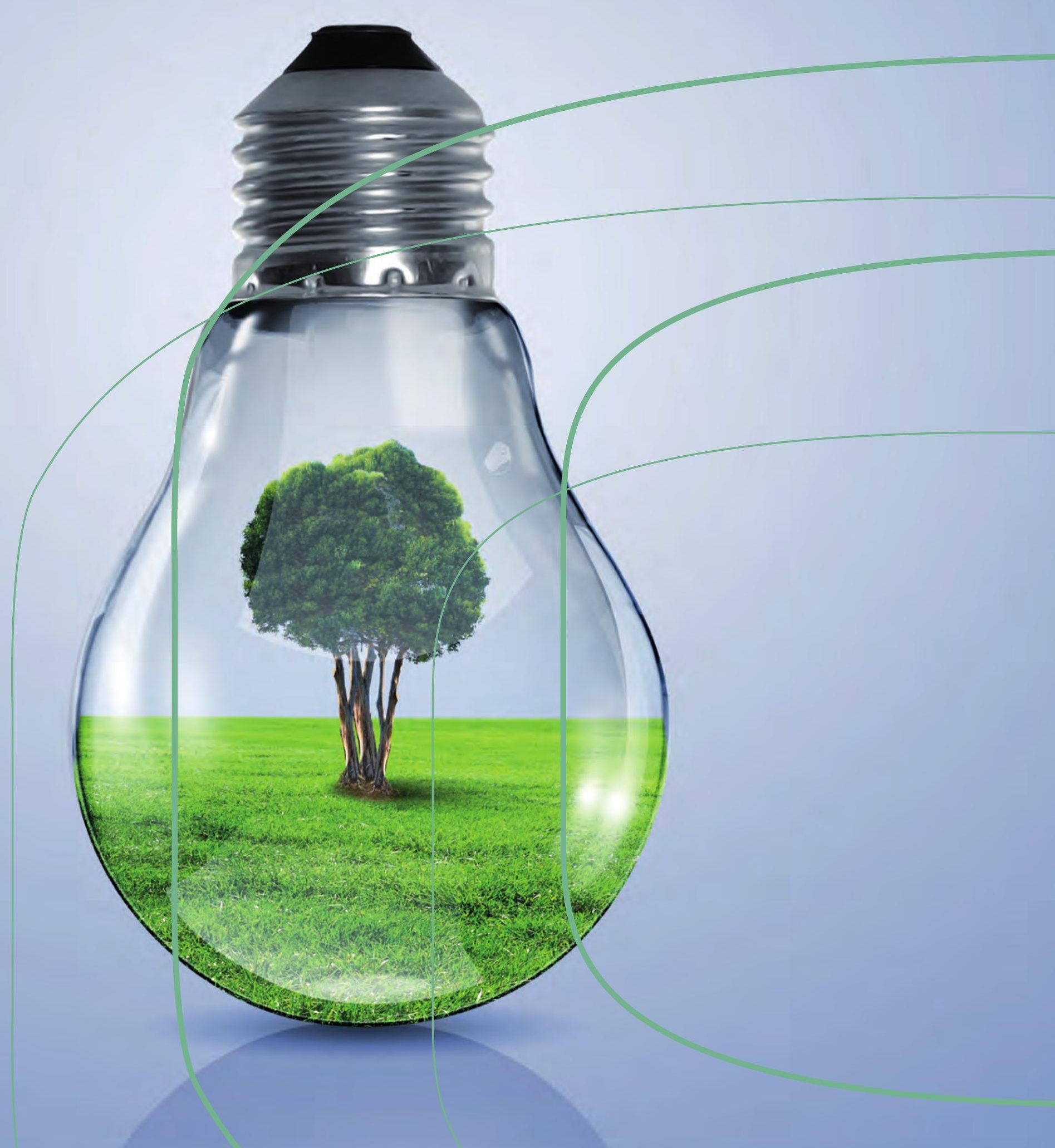



2 norden 



\section{Future EU energy and climate regulation}

Implications for Nordic energy development and Nordic stakeholders

Ea Energy Analyses A/S

TemaNord 2014:570 
Future EU energy and climate regulation

Implications for Nordic energy development and Nordic stakeholders

Ea Energy Analyses A/S

ISBN 978-92-893-3892-9(PRINT)

ISBN 978-92-893-3894-3 (PDF)

ISBN 978-92-893-3893-6 (EPUB)

http://dx.doi.org/10.6027/TN2014-570

TemaNord 2014:570

ISSN 0908-6692

(C) Nordic Council of Ministers 2015

Layout: Hanne Lebech

Cover photo: Signelements

Print: Rosendahls-Schultz Grafisk

Printed in Denmark

This publication has been published with financial support by the Nordic Council of Ministers. However, the contents of this publication do not necessarily reflect the views, policies or recommendations of the Nordic Council of Ministers.

www.norden.org/en/publications

\section{Nordic co-operation}

Nordic co-operation is one of the world's most extensive forms of regional collaboration, involving Denmark, Finland, Iceland, Norway, Sweden, and the Faroe Islands, Greenland, and Åland.

Nordic co-operation has firm traditions in politics, the economy, and culture. It plays an important role in European and international collaboration, and aims at creating a strong Nordic community in a strong Europe.

Nordic co-operation seeks to safeguard Nordic and regional interests and principles in the global community. Common Nordic values help the region solidify its position as one of the world's most innovative and competitive.

\section{Nordic Council of Ministers}

Ved Stranden 18

DK-1061 Copenhagen K

Phone (+45) 33960200

www.norden.org 


\section{Content}

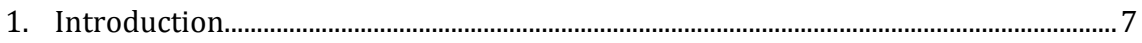

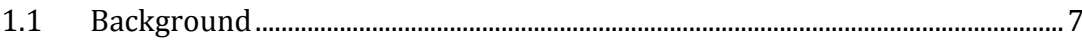

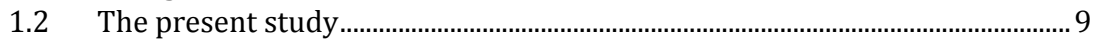

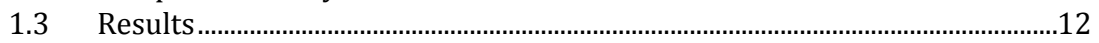

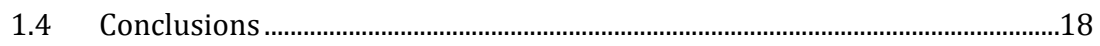

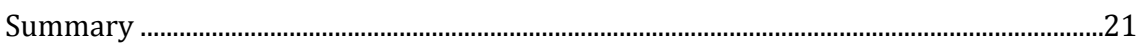

2. Methodology and key assumptions ..................................................................................23

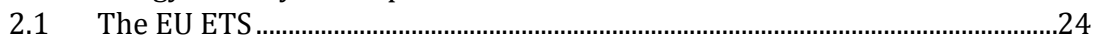

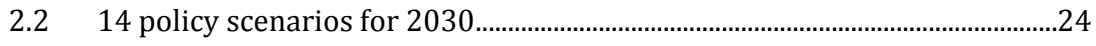

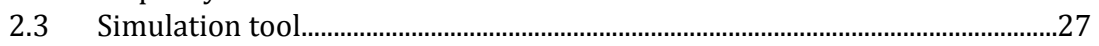

2.4 Investments in new generation capacity ..........................................................27

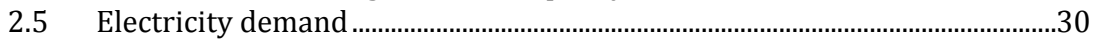

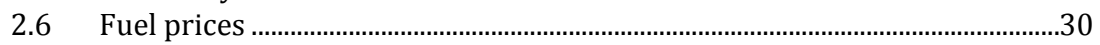

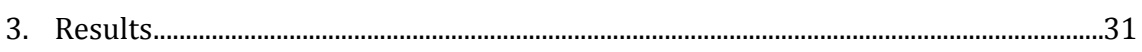

3.1 Scenario 1 ..................................................................................................

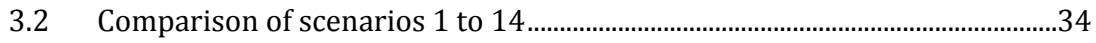

3.3 Impact of renewable energy sources on electricity prices.................................38

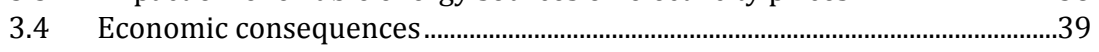

4. Sammenfatning ........................................................................................................................4 



\section{Introduction}

\subsection{Background}

The European Union has an objective of reducing greenhouse gas emissions by $80-95 \%$ in 2050 relative to 1990 . The roadmap for moving to a competitive low carbon economy in 2050 explores different pathways up to 2050 that could enable the EU to reduce greenhouse gas reductions in line with the 80 to $95 \%$ target.

In particular, the electricity sector will play a key role in the transformation of energy systems. By 2050, $\mathrm{CO}_{2}$ emissions from the electricity sector should be almost totally eliminated, thus offering the prospect of only partially replacing fossil fuels in other sectors, such as the transport sector, where alternative low carbon options are more limited.

Figure 1: A pathway for reducing greenhouse gas emissions in the EU ("A Roadmap for moving to a competitive low carbon economy in 2050," COM (2011) 112 final)

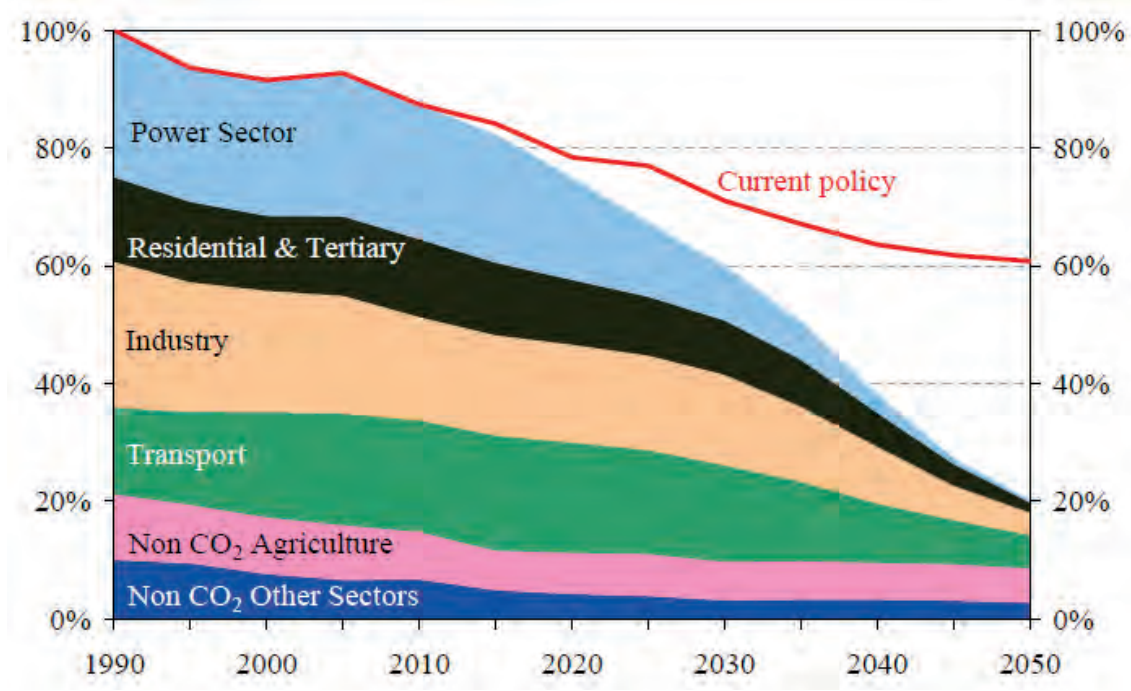




\section{Energy and climate targets for 2020}

In 2007, the EU Heads of State and Government set a series of climate and energy targets to be met by 2020, known as the "20-20-20" targets.

The achievement of the EU's 20/20/20 objectives for 2020 rely on regulation of greenhouse gas emissions, the development of renewable energy (RE) and an increase in energy efficiency through:

- Emission trading - Including reducing the amount of allowances under the ETS, and gradually replacing the quota-allocation with quota auctioning.

- Binding national targets for the reduction of greenhouse gas emissions from sectors not covered by the ETS - with higher reductions for wealthy countries and limited increases for the poorest.

- Binding national targets for the share of renewable energy, with specific targets for transport fuels.

- Energy efficiency targets, including those stated in the EU Directive on Energy Efficiency of 25 October 2012 (2012/27/EU). This does not entail a binding national target, but instead a binding choice of instruments and sub-targets.

\section{0 targets under discussion}

In March 2013, the European Commission published the Green Paper "A 2030 framework for climate and energy policies." In January 2014, the green paper was followed up by a proposal by the European Commission for a 2030 policy framework for climate and energy. Unlike the 2020 framework, the Commission does not propose binding national targets for renewable energy, but the proposal includes an objective of increasing the share of renewable energy to at least $27 \%$ at the EU level. At the same time, improvements in energy efficiency are recognised as essential, but specific energy targets are not part of the proposal.

\section{AGFE Seminar 27th November 2013}

In November 2013, the Renewable Energy Working Group (AGFE) of the Nordic Council of Ministers arranged a seminar in Copenhagen, Denmark, to explore renewable energy policy in the Nordic countries post 2030. A preliminary model analysis of future EU energy and climate regulation was prepared expressly for the seminar by Ea Energy Analyses. This report describes the results from the model analysis. The results presented at the seminar in Copenhagen have been supplemented with additional simulations on key parameters after discussions with the AGFE, and some of the assumptions have also been revised. 
Central in the proposal is a target to reduce EU domestic greenhouse gas emissions by $40 \%$ below the 1990 level by 2030 . Within the power sector, the EU Commission sees a revitalised emissions trading scheme as the key measure to achieve the needed $\mathrm{CO}_{2}$ reductions. The EU ETS is currently faced with a growing surplus of allowances and international credits, which has led to very low carbon prices. The Commission proposes to establish a so-called market stability reserve at the beginning of the next trading period in 2021 to address the surplus of emission credits.

The European Parliament, in February 2014, called for a nationally binding renewable energy target - $30 \%$ at the EU level - and a target for energy efficiency.

EU leaders are currently discussing the targets for 2030, including whether or not the 2020 framework with separate targets for GHG emissions, renewable energy and energy efficiency should be continued. The hope is that an agreement will be in place well ahead of an expected global climate agreement in 2015.

\subsection{The present study}

The present study analyses the impact of different EU energy and climate policy measures on the electricity markets in the Nordic countries and Germany in 2030, assessing among other things:

- What will the composition of electricity generation look like?

- What will be the share of renewable energy generation?

- How will $\mathrm{CO}_{2}$ prices develop?

- What are the implications for electricity generation?

- Which stakeholders will benefit from different types of policy regulation, and what are the socio-economic consequences?

The analyses undertaken cover the power systems of the Nordic countries and Germany, where electricity generation amounts to just below $1,000 \mathrm{TWh}$, or close to $1 / 3$ of the total power production in the EU27. ${ }^{1}$

\footnotetext{
1 Electricity generation in the EU27 is just above 3,000 TWh. Source: http://epp.eurostat.ec.europa.eu/ statistics_explained/images/2/29/EU-27_Evolution_of_electricity_supplied\%2C_2003-2012_\%28in_GWh\%29.png
} 


\section{Modelling tool}

The electricity market model Balmorel is utilised to simulate optimal dispatch and investments in power plants given input framework conditions and technology costs.

Balmorel is a least cost power system model. The model is based on a detailed technical representation of the existing power system; power and heat generation facilities, as well as the most important bottlenecks in the overall transmission grid.

\section{How much should the power sector contribute by 2030?}

According to the EU Commission's climate road-map, the electricity sector is foreseen to deliver large GHGs reductions in the medium term. By 2030, the electricity sector's emissions should decrease by $54-68 \%$ compared to 1990 , whereas emissions from all sectors should decrease by $40-44 \%$.

The reference assumption in the scenario analyses in this study is a $\mathrm{CO}_{2}$ reduction of $50 \%$ compared to 2005 . This corresponds to an approximate $54 \%$ reduction relative to 1990 emissions. In addition, variations are made with reductions of 30\%, 40\% and 60\% compared to 2005.

According to the Commission's proposal from January 2014, in order to achieve the overall $40 \%$ target, the sectors covered by the EU emissions trading system (EU ETS) would have to reduce their emissions by $43 \%$ compared to 2005. However, this target cannot be directly transposed to the power sector, as the EU ETS also includes energy intensive industries, with aviation serving as one example.

Figure 2: A pathway for reducing greenhouse gas emissions in the EU ("A Roadmap for moving to a competitive low carbon economy in 2050," COM (2011) 112 final)

\begin{tabular}{|l|c|c|c|}
\hline GHG reductions compared to 1990 & 2005 & 2030 & 2050 \\
\hline Total & $-7 \%$ & -40 to $-44 \%$ & -79 to $-82 \%$ \\
\hline Sectors & \multicolumn{3}{|l|}{} \\
\hline Power $\left(\mathrm{CO}_{2}\right)$ & $-7 \%$ & -54 to $-68 \%$ & -93 to $-99 \%$ \\
\hline Industry $\left(\mathrm{CO}_{2}\right)$ & $-20 \%$ & -34 to $-40 \%$ & -83 to $-87 \%$ \\
\hline Transport (incl. $\mathrm{CO} 2$ aviation, excl. maritime) & $+30 \%$ & +20 to $-9 \%$ & -54 to $-67 \%$ \\
\hline Residential and services $\left(\mathrm{CO}_{2}\right)$ & $-12 \%$ & -37 to $-53 \%$ & -88 to- $-91 \%$ \\
\hline Agriculture (non- $\mathrm{CO}_{2}$ ) & $-20 \%$ & -36 to $-37 \%$ & -42 to $-49 \%$ \\
\hline Other non- $\mathrm{CO}_{2}$ emissions & $-30 \%$ & -72 to $-73 \%$ & -70 to $-78 \%$ \\
\hline
\end{tabular}




\section{Purpose of the current study}

Within the current study, 14 policy scenarios for the development towards 2030 are analysed, exploring different combinations of climate and energy policies.

The starting point (Scenario 1) looks at a situation where the EU ETS is the only climate regulation imposed. The $\mathrm{CO}_{2}$ reduction target achieved in the power sector is 50\% compared to 2005 levels, which is in line with the objectives of the EU's "Roadmap for moving to a competitive low carbon economy in 2050" (see text box).

In the other scenarios, the consequences of alternative policies and framework conditions are assessed, including:

- applying subsidies to renewable energy generation

- higher energy efficiency (lower electricity demand)

- a less stringent $\mathrm{CO}_{2}$ cap (30 and $40 \%$ reductions)

- a more stringent $\mathrm{CO}_{2}$ cap (a $60 \%$ reduction)

- not allowing investments in new coal power capacity

- lower natural gas prices

- changed investor behaviour (higher risk premium)

- higher integration of electricity grids in the region.

\section{$\mathrm{CO}_{2}$-prices are calculated by the model}

When the $\mathrm{CO}_{2}$ caps are imposed on emissions from power and district heating plants in the Nordic countries and Germany, the model is able to compute the marginal costs of reducing $\mathrm{CO}_{2}$ emissions. This marginal cost can be interpreted as the price of $\mathrm{CO}_{2}$ allowances if the power and heat generators in the Nordic countries and Germany were the only participants in the EU ETS. In practice, the EU ETS $\mathrm{CO}_{2}$-price will be determined based on supply and demand from all companies under the ETS, including companies in other EU countries, companies from other sectors than power and heat and with the impact of imported credits from CDM projects. Hence, the $\mathrm{CO}_{2}$ prices resulting from the simulations should not be interpreted as a forecast of the $\mathrm{CO}_{2}$ prices within the $\mathrm{EU}$ ETS, but the dynamics within the EU ETS can be expected to resemble those modelled in the present study. 


\begin{tabular}{|c|c|c|c|}
\hline \multirow[t]{2}{*}{ Scenario } & \multicolumn{3}{|c|}{ Scenario assumptions } \\
\hline & CO2 target & RE subsidy & Other changes \\
\hline 2013 & & RE targets & \\
\hline 2020 & & RE targets & \\
\hline 1 & $50 \%$ & None & \\
\hline 2 & $50 \%$ & $€ 20 / M W h$ & \\
\hline 3 & $50 \%$ & $€ 20 / M W h$ & Lower electricity demand (-5\%) \\
\hline 4 & $40 \%$ & None & \\
\hline 5 & $30 \%$ & None & \\
\hline 6 & $50 \%$ & None & Ban on new coal power \\
\hline 7 & $30 \%$ & None & Ban on new coal power \\
\hline 8 & $30 \%$ & $€ 20 / M W h$ & Ban on new coal power \\
\hline 9 & $50 \%$ & None & Natural gas price reduced $20 \%$ \\
\hline 10 & $50 \%$ & None & $10 \%$ real interest rate ${ }^{* *}$ \\
\hline 11 & $50 \%$ & None & No limit on trans. investment \\
\hline 12 & $50 \%$ & $€ 30 / M W h$ & Subsidy only to offshore/PV \\
\hline 13 & $50 \%$ & $€ 20 / M W h$ & Natural gas price reduced by $20 \%$ \\
\hline 14 & $60 \%$ & None & \\
\hline
\end{tabular}

${ }^{*} \mathrm{CO}_{2}$ prices in 2013 and 2020 are assumptions and are not a result of the simulations.

** Investors required rate of return; this rate is $5 \%$ in the other scenarios.

\subsection{Results}

\section{Electricity generation}

In 2013, the share of renewable energy in the electricity supply in the region being analysed was 39\% (model result). Already towards 2020 a very noticeable change in the electricity supply mix can be observed, which is a result of the existing policies, the renewable energy targets and the EU ETS. These policies lead to a reduction in $\mathrm{CO}_{2}$ emissions of about $40 \%$ by 2020 compared to 1990 , and the share of RE increases to $56 \%$.

Figure 3 displays the annual electricity generation in the entire region in 2030 for each of the scenarios analysed, whereas table 1 displays the scenario assumptions together with key results in terms of realised $\mathrm{CO}_{2}$ emissions, $\mathrm{CO}_{2}$ prices, electricity prices and RE shares.

\section{Renewable energy shares}

The share of renewable energy varies between $56 \%$ and $69 \%$ in the scenarios for 2030. In scenario 1 , with the $50 \% \mathrm{CO}_{2}$ cap, the renewable share is just below $60 \%$. In scenario 2 , when RE is subsidised by $€ 20 / \mathrm{MWh}$, the share increases moderately to $61 \%$ ( +1.5 percentage point, $+16 \mathrm{TWh})$.

The renewable energy technologies deployed in 2020 remain in place in 2030 in all scenarios. Therefore, $\mathrm{CO}_{2}$ emissions in 2030 turn out to be $41 \%$ lower than in 1990 , even if there is no price on $\mathrm{CO}_{2}$. Therefore, sce- 
nario 5, which includes an emission target of only $30 \%$, becomes irrelevant as it turns out to be identical with scenario 4 , where the target is $40 \%$. Scenario 4 (and 5) also demonstrate the lowest share of renewable energy, $56 \%$ as in 2020 .

\section{Ban on new coal power}

In scenarios 6 and 7, investments in new coal power plants are not permitted. As the existing power plants in the model have a specified technical lifetime, this becomes a powerful policy measure resulting in strong emission reduction of approximately $55 \%$. This is well above the targets of 50\% (scenario 6), and 30\% (scenario 7) specified for the two scenarios, and therefore scenario 7 turns out identical to scenario 6 .

Figure 3: Development electricity generation (TWh), 2010, 2020 and 2030 (Scenario 1-14). Scenario 5 is identical with scenario 4. Scenario 7 is identical with scenario 6

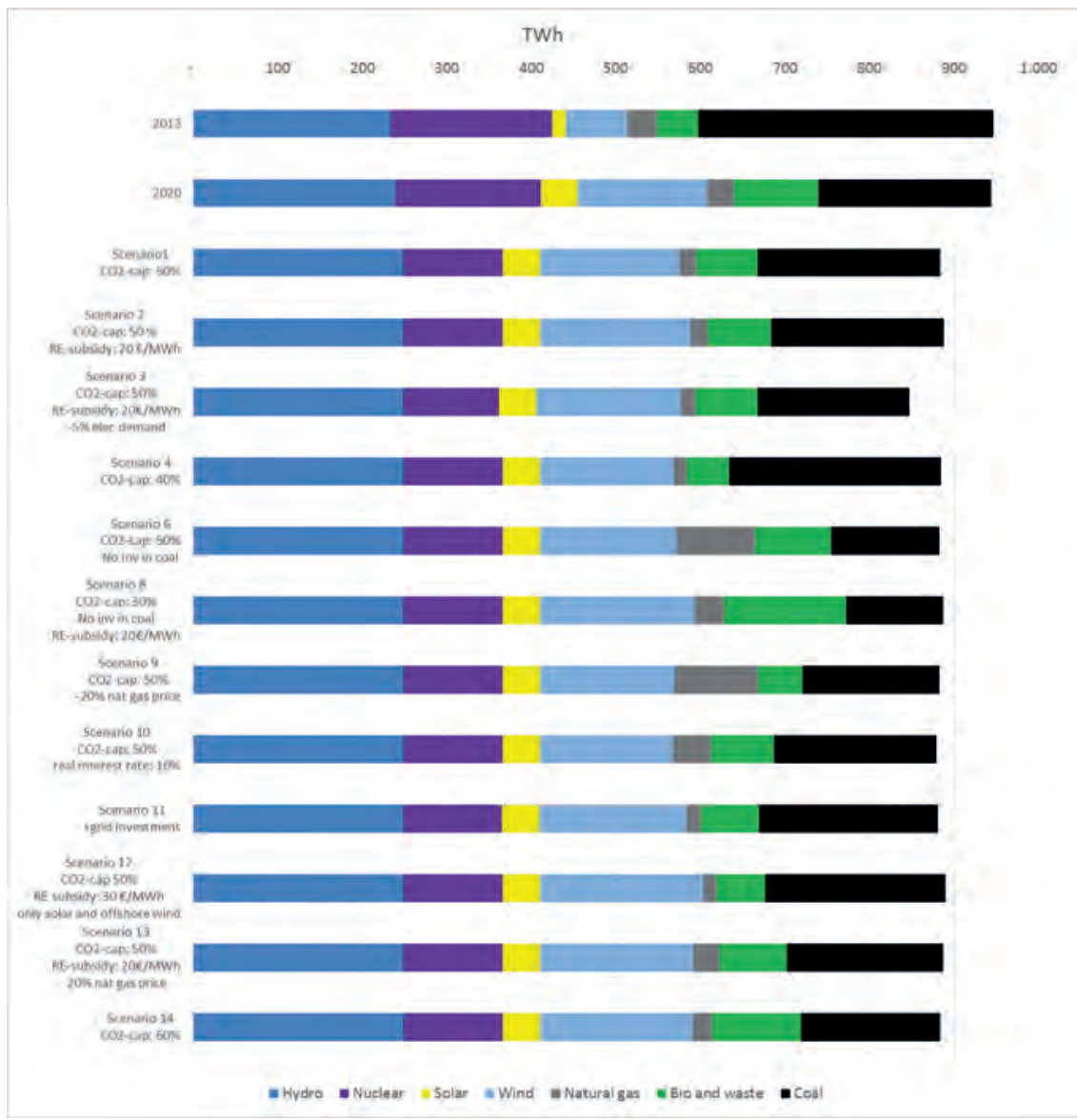

In scenario 8, the ban on new coal fired capacity is combined with subsidies to renewable energy, leading to even stronger $\mathrm{CO}_{2}$ reductions of 
approximately 64\%. This scenario also demonstrate the highest RE share $(69 \%)$ in any of the scenarios. In all three scenarios, where investments in new coal power capacity are not allowed, the price of $\mathrm{CO}_{2}$ drops to zero, because emission reductions exceed the specified targets.

\section{Gas-coal split}

In comparing scenarios 9 and 1, it becomes apparent that the trade-off between gas and coal is quite sensitive to the price of gas, which is $20 \%$ lower in scenario 9. The lower gas price leads to both less coal power generation, and less renewable energy.

When a renewable subsidy of $€ 20 / M W h$ is added to the case of lower gas price (illustrated in scenario 13), the share of gas is again reduced significantly and the renewable energy share soars back to approx. the same level as in scenario 2. The large deployment of renewable energy also causes the price of $\mathrm{CO}_{2}$ to drop to zero. This provides room for more coal power based generation.

It is also interesting to note, that the impact of the renewable energy subsidy is much greater in the case of lower gas prices. Using our reference gas the subsidy only leads to $1.5 \%$-point increase (Sc. 2 vs. Sc. 1 ) in the RE share but at low gas prices the increase cause by the subsidies is $5.2 \%$-point (Sc 13 vs Sc. 9).

\section{Higher discount rate}

A higher investor discount rate (scenario 10), also increases the share of gas power at the expense of the more capital intensive renewable energy technologies and coal power.

\section{Transmission capacity}

The model is allowed to invest in additional interconnectors if this is economically feasible, but certain limits are imposed to account for noneconomic barriers, such as environmental constraints and time to plan and implement the projects. When these constraints are removed (scenario 11), the result is larger investments in wind power $(+8.5 \mathrm{TWh})-$ as balancing the wind power becomes cheaper - and a small reduction in the price of $\mathrm{CO}_{2}$.

\section{Stronger $\mathrm{CO}_{2}$ target}

If the $\mathrm{CO}_{2}$ target is increased to a $60 \%$ reduction (sc. 14), the result is an increased share of renewables - in particular biomass - at the expense of coal power (RE share reaches 64\%). Gas power generation also increases slightly compared to scenario 1 , where the $\mathrm{CO}_{2}$ cap is $50 \%$. In 
the current case, the price of $\mathrm{CO}_{2}$ reaches $€ 36$ /ton, the highest level of all scenarios analysed.

\begin{tabular}{|c|c|c|c|c|c|c|c|c|}
\hline \multirow{2}{*}{$\begin{array}{l}\text { Scena- } \\
\text { rio }\end{array}$} & \multirow[b]{2}{*}{$\begin{array}{l}\mathrm{CO}_{2} \\
\text { target }\end{array}$} & \multicolumn{2}{|c|}{ Scenario assumptions } & \multicolumn{4}{|c|}{ Key Results } & \multirow[b]{2}{*}{$\begin{array}{r}\text { RE } \\
\text { share }\end{array}$} \\
\hline & & RE subsidy & Other changes & $\begin{array}{r}\mathrm{CO}_{2} \\
\text { price } \\
€ / \mathrm{t}\end{array}$ & $\begin{array}{r}\mathrm{CO}_{2} \\
\text { targetM } \\
\text { getM- } \\
\text { ton } / \mathrm{y}\end{array}$ & $\begin{array}{r}\text { Realised } \\
\mathrm{CO}_{2} \\
\text { emissi- } \\
\text { onsMton/y }\end{array}$ & $\begin{array}{r}\text { Power } \\
\text { price } \\
€ / \mathrm{MWh}\end{array}$ & \\
\hline 2013 & & RE targets & & 5.2 & & 402 & 48.5 & $39 \%$ \\
\hline 2020 & & RE targets & & 10.0 & & 244 & 49.4 & $56 \%$ \\
\hline 1 & $50 \%$ & None & & 19.7 & 210 & 210 & 54.1 & $60 \%$ \\
\hline 2 & $50 \%$ & $€ 20 / M W h$ & & 0.5 & 210 & 210 & 37.8 & $61 \%$ \\
\hline 3 & $50 \%$ & $€ 20 / M W h$ & Lower elec. demand (-5\%) & 0.0 & 210 & 191 & 32.0 & $63 \%$ \\
\hline 4 & $40 \%$ & None & & 0.0 & 247 & 241 & 42.6 & $56 \%$ \\
\hline 5 & $30 \%$ & None & & 0.0 & 284 & 241 & 42.6 & $56 \%$ \\
\hline 6 & $50 \%$ & None & Ban on new coal power & 0.0 & 210 & 192 & 48.7 & $61 \%$ \\
\hline 7 & $30 \%$ & None & Ban on new coal power & 0.0 & 284 & 192 & 48.7 & $61 \%$ \\
\hline 8 & $30 \%$ & $€ 20 / M W h$ & Ban on new coal power & 0.0 & 284 & 158 & 40.7 & $69 \%$ \\
\hline 9 & $50 \%$ & None & Nat.gas price reduced $20 \%$ & 13.3 & 210 & 210 & 49.5 & $57 \%$ \\
\hline 10 & $50 \%$ & None & $10 \%$ real interest rate $* *$ & 20.7 & 210 & 210 & 58.4 & $59 \%$ \\
\hline 11 & $50 \%$ & None & No limit on trans. investment & 18.6 & 210 & 210 & 55.8 & $60 \%$ \\
\hline 12 & $50 \%$ & $€ 30 / \mathrm{MWh}$ & Subsidy only to offshore/PV & 14.1 & 210 & 210 & 39.8 & $61 \%$ \\
\hline 13 & $50 \%$ & $€ 20 / M W h$ & Nat.gas price reduced $20 \%$ & 0.0 & 210 & 204 & 36.7 & $62 \%$ \\
\hline 14 & $60 \%$ & None & & 36.0 & 172 & 172 & 58.6 & $64 \%$ \\
\hline
\end{tabular}

${ }^{*} \mathrm{CO}_{2}$ prices in 2013 and 2020 are assumptions and therefore not a result of the simulations.

** Investors required rate of return; this rate is $5 \%$ in the other scenarios. The power price is a simple average of the weighted annual average power price in each of the five countries included in the analysis.

\section{RE subsides leads to lower electricity market prices}

It is interesting to note that in the scenarios where renewable energy subsidies are used, a significant downward impact on electricity market prices is realised. The reason for this is two-fold: Firstly, renewable energy becomes more competitive with fossil fuels and therefore a lower $\mathrm{CO}_{2}$ price is required to meet the reduction targets. The lower $\mathrm{CO}_{2}$ price leads to lower costs of fossil fuel based power production. Secondly, power plants that receive a subsidy will bid at a lower price in the spot market. As a consequence we will see lower power prices both when fossil fuel generators and renewable energy generators provide the marginal power in the electricity market. 


\section{Impact assessment of $\mathbf{2 0 3 0}$ framework for climate and energy policies}

In January of 2014, the EU Commission proposed to reduce EU domestic greenhouse gas emissions by $40 \%$ below the 1990 level by 2030. The proposal by the Commission was supported by an impact assessment, which through a series of scenarios has analysed the consequences of different policy options and ambition levels.

The scenarios address various combinations of greenhouse gas (GHG) reduction targets, targets for renewable energy deployment and energy saving levels. The scenarios are set under different framework conditions; reference conditions and a so-called enabling conditions which assume among other things, higher level energy infrastructure development, R\&D and innovation, electrification of transport and greater potentials for reducing energy demand.

The scenarios are compared to a reference scenario providing a projection of expected developments under already agreed policies. In the reference scenario, GHG emissions on EU level are reduced by 32\% in 2030 compared to 1990 , and the share of renewable energy is increased to $24 \%$. In the scenario underlying the Commission's proposal, GHG emissions are reduced by $40 \%$ (pre-set target) and the share of renewable energy increased to $26 \%$. In the power sector, the share of renewable energy is significantly higher amounting to $43 \%$ in the reference, and $47 \%$ in the GHG40 scenario. If the $40 \%$ GHG reduction target is combined with a $30 \%$ RES target and increased energy saving measures, the renewable energy share in the electricity sector would increase to $53 \%$ by 2030 .

Renewable energy shares in power generation in the reference scenario, the $40 \%$ GHG reduction scenario and the $\mathbf{4 0} \%$ GHG reduction scenario with $30 \%$ renewable energy target

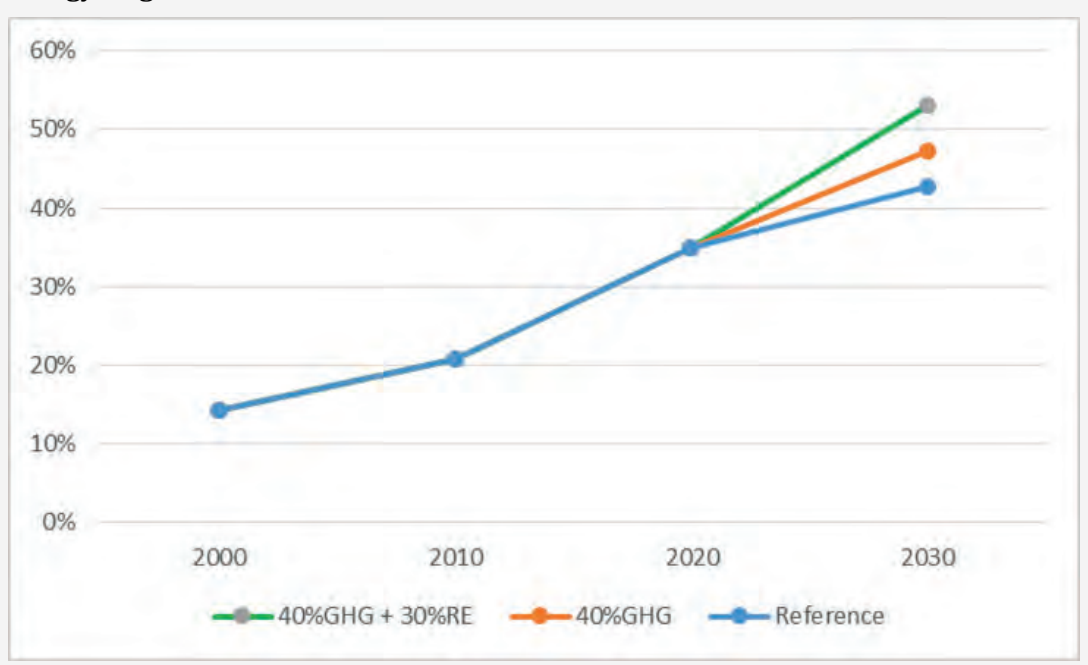

In the reference scenario, the ETS $\mathrm{CO}_{2}$ price is forecasted to be $€ 35$ /ton, compared to $€ 40$ /ton in the GHG40 scenario and only €11/ton in the scenario with a 30\% RE target and increased energy efficiency measures. The premium required to ensure a $30 \%$ share of renewable energy has been estimated to be $€ 56 / \mathrm{MWh}$. 


\section{Economic results}

The economic analyses show that for the region as a whole, consumers will benefit from introducing renewable subsidies, which are applied in scenario 2, whereas generators and the public face higher costs. The reason for this is that the renewable energy subsidies lead to lower electricity prices, which directly benefits consumers. It is assumed that electricity consumers pay for the renewable energy subsidies, but in most countries - Denmark being an exception - this cost is lower than the savings realised due to the lower market price for electricity. In all countries, the state loses revenues from the auctioning of $\mathrm{CO}_{2}$ quotas, as the $\mathrm{CO}_{2}$ quota price is reduced when RE subsidies are introduced.

In Germany and Denmark, where the share of subsidised generation (i.e. solar, wind and biomass) are highest, generators also profit from the introduction of RE subsidies.

\begin{tabular}{|c|c|c|c|c|c|c|}
\hline Mill. EUR-2013 & Denmark & Finland & Germany & Norway & Sweden & Total \\
\hline Generator profits: & 173 & $-1,243$ & 1,790 & $-2,548$ & $-2,737$ & $-4,565$ \\
\hline Consumer surplus: & -75 & 1,662 & 2,292 & 1,925 & 2,263 & 8,067 \\
\hline TSO profit: & 69 & -66 & 205 & 135 & 87 & 429 \\
\hline State profit: & -69 & -195 & $-3,661$ & -24 & -71 & $-4,020$ \\
\hline Socio economic benefit: & 97 & 159 & 625 & -511 & -458 & -89 \\
\hline
\end{tabular}

When the focus shifts to the distribution of benefits and costs between countries - i.e. summing the economics of producers, consumers, TSO and the state within each country - Germany, Finland and Denmark benefit from RE subsidies (scenario 2 compared to scenario 1), whereas Sweden and Norway will have their costs increased. The reason for this is that Germany, Finland and Denmark are net importers of electricity, and therefore take advantage of lower electricity market prices - whereas the opposite is the case for Sweden and Norway.

In total, the socio-economic cost of scenario 2 is $€ 89$ million higher than in scenario 1 . This is the annual socio-economic cost for the whole modelling area, which can be attributed to the introduction of renewable energy subsidies compared to only having an ETS target. For comparison, the annual turnover of all power and heat generators in the analysed region amounts to just $€ 58.8$ billion in scenario 1 . Relative to that figure the additional cost of scenario 2 is $0.15 \%$.

Scenario 3 leads to a significant benefit $(+3.6 \%)$ relative to scenario 1 , but this should be compared to the cost of implementing the energy savings, which are included in this scenario. This analysis has not been undertaken. 
Reducing the $\mathrm{CO}_{2}$ target from $50 \%$ to $40 \%$ (scenario 4) reduces the relative costs by $0.76 \%$, whereas increasing the target to $60 \%$ leads to a cost increase of $1.68 \%$.

The scenarios involving a ban on coal power exhibit relatively high costs, but also demonstrate significant $\mathrm{CO}_{2}$ reductions. By comparing scenario 6 and scenario 1 , the average cost of the additional $\mathrm{CO}_{2}$ reductions in scenario 6 are found to be $€ 63$ per tonne. Scenario 8, which combines the ban on coal with subsidies to renewables, increases the relative costs by roughly $3.8 \%$, but it also presents the highest RE share $(69 \%)$ and the lowest $\mathrm{CO}_{2}$ emissions. The additional socio-economic cost in scenario 8 (compared to scenario 1 ) amounts to $€ 44 /$ ton $\mathrm{CO}_{2}$ or $€ 25$ per MWh of renewable electricity generation.

Table 3 displays the economic consequences for each of scenarios 2-14 compared to scenario 1 .

\begin{tabular}{|c|c|c|c|c|c|c|c|c|}
\hline \multirow{2}{*}{$\begin{array}{l}\text { Sce- } \\
\text { nario }\end{array}$} & \multicolumn{3}{|c|}{ Scenario assumptions } & \multirow{2}{*}{$\begin{array}{r}\text { Con- } \\
\text { sumer } \\
\text { Surplus }\end{array}$} & \multirow{2}{*}{$\begin{array}{c}\text { Gene- } \\
\text { rator } \\
\text { Profits }\end{array}$} & \multirow{2}{*}{$\begin{array}{r}\text { Public } \\
\text { Profit }\end{array}$} & \multirow{2}{*}{$\begin{array}{r}\text { Total Socio } \\
\text { Economic } \\
\text { Benefit }\end{array}$} & \multirow{2}{*}{$\begin{array}{r}\text { Relative } \\
\text { cost* }\end{array}$} \\
\hline & $\begin{array}{l}\mathrm{CO}_{2} \\
\text { target }\end{array}$ & $\begin{array}{l}\text { RE } \\
\text { subsidy }\end{array}$ & Other changes & & & & & \\
\hline 1 & $50 \%$ & None & & 0 & 0 & 0 & 0 & \\
\hline 2 & $50 \%$ & $€ 20 / M W h$ & & 8,067 & $-4,565$ & $-3,591$ & -89 & $0.15 \%$ \\
\hline 3 & $50 \%$ & $€ 20 / M W h$ & Lower elec. demand (-5\%) & 14,326 & $-9,047$ & $-3,166$ & 2,114 & $-3.59 \%$ \\
\hline 4 & $40 \%$ & None & & 11,202 & $-6,363$ & $-4,390$ & 449 & $-0.76 \%$ \\
\hline 5 & $30 \%$ & None & & 11,202 & $-6,363$ & $-4,390$ & 449 & $-0.76 \%$ \\
\hline 6 & $50 \%$ & None & Ban on new coal power & 2,951 & -757 & $-3,319$ & $-1,126$ & $1.91 \%$ \\
\hline 7 & $30 \%$ & None & Ban on new coal power & 2,951 & -757 & $-3,319$ & $-1,126$ & $1.91 \%$ \\
\hline 8 & $30 \%$ & $€ 20 / M W h$ & Ban on new coal power & 2,581 & $-1,741$ & $-3,082$ & $-2,243$ & $3.81 \%$ \\
\hline 9 & $50 \%$ & None & Nat.gas price reduced $20 \%$ & 4,858 & $-2,744$ & $-1,514$ & 600 & $-1.02 \%$ \\
\hline 10 & $50 \%$ & None & $10 \%$ real interest rate $* *$ & $-6,754$ & 5,616 & 1,020 & -117 & $0.20 \%$ \\
\hline 11 & $50 \%$ & None & No limit on trans. Investment & $-1,759$ & 2,647 & -659 & 229 & $-0.39 \%$ \\
\hline 12 & $50 \%$ & $€ 30 / M W h$ & Subsidy only to offshore/PV & 5,818 & $-6,564$ & 179 & -568 & $0.97 \%$ \\
\hline 13 & $50 \%$ & $€ 20 / M W h$ & Nat.gas price reduced $20 \%$ & 4,579 & -624 & $-3,761$ & 194 & $-0.33 \%$ \\
\hline 14 & $60 \%$ & None & & $-6,234$ & 2,295 & 2,948 & -990 & $1.68 \%$ \\
\hline
\end{tabular}

*The relative cost is calculated as the total socio-economic cost compared to the annual turnover of power and heat generators in the region ( $€ 58.8$ billion).

\subsection{Conclusions}

The analyses reveal that there is a very high degree of interdependency of the different policy measures used to achieve climate and energy targets. If subsidies are used to support renewable energy technologies this will have a significant downward impact on the price of $\mathrm{CO}_{2}$. The same is the case if investments in new coal power generation are not allowed or if electricity demand is reduced. 
Moreover, the choice of policy measures have significant impacts on electricity market prices. Renewable subsidies lead to significantly lower electricity market prices. The implication of this is also that the prices we see on the electricity spot markets do not necessarily reveal the true cost of producing power.

Renewable energy subsidies may provide greater certainty for investors, as well as greater certainty regarding the achievement of the long term targets. The analyses reveal that the impact of renewable energy subsidies is very much dependent on the framework conditions. If the price of natural gas develops to lower level than the IEA expects renewable energy subsidies would be very important to uphold the renewable energy share. The total socioeconomic cost of introducing renewable energy subsidies is modest compared to the ETS only model, but implications on stakeholder economy are significant. In general, electricity producers benefit from a situation with EU ETS only, whereas consumers benefit from a situation where renewable energy subsidies are also applied.

Alternative forms of regulation, such as putting a ban on the establishment of particular power plants, could be a very effective measure to reduce $\mathrm{CO}_{2}$ emissions, particularly if it is combined with subsidies for renewable energy. However, this type of regulation also appears to be more costly.

A reduction in electricity demand will lower the costs to consumers directly - less power need to be purchased - and indirectly as a reduction in the demand for power also leads to lower electricity prices. 



\section{Summary}

The European Union has an objective of reducing greenhouse gas emissions by $80-95 \%$ in 2050 relative to 1990 . The roadmap for moving to a competitive low carbon economy in 2050 explores different pathways up to 2050 that could enable the EU to reduce greenhouse gas reductions in line with the 80 to $95 \%$ target.

In 2007, the EU Heads of State and Government set a series of climate and energy targets to be met by 2020, known as the "20-20-20" targets.

EU leaders are currently discussing the targets for 2030, including whether or not the 2020 framework with separate targets for GHG emissions, renewable energy and energy efficiency should be continued. The hope is that an agreement will be in place well ahead of an expected global climate agreement in 2015.

The present study analyses the impact of different EU energy and climate policy measures on the electricity markets in the Nordic countries and Germany in 2030, assessing among other things:

- What will the composition of electricity generation look like?

- What will be the share of renewable energy generation?

- How will CO2 prices develop?

- What are the implications for electricity generation?

- Which stakeholders will benefit from different types of policy regulation, and what are the socio-economic consequences?

The analyses undertaken cover the power systems of the Nordic countries and Germany, where electricity generation amounts to just below $1,000 \mathrm{TWh}$, or close to $1 / 3$ of the total power production in the EU27.

The analyses reveal that there is a very high degree of interdependency of the different policy measures used to achieve climate and energy targets. If subsidies are used to support renewable energy technologies this will have a significant downward impact on the price of $\mathrm{CO}_{2}$. The same is the case if investments in new coal power generation are not allowed or if electricity demand is reduced.

Moreover, the choice of policy measures have significant impacts on electricity market prices. Renewable subsidies lead to significantly lower electricity market prices. The implication of this is also that the prices 
we see on the electricity spot markets do not necessarily reveal the true cost of producing power.

Alternative forms of regulation, such as putting a ban on the establishment of particular power plants, could be a very effective measure to reduce $\mathrm{CO}_{2}$ emissions, particularly if it is combined with subsidies for renewable energy. However, this type of regulation also appears to be more costly.

A reduction in electricity demand will lower the costs to consumers directly - less power need to be purchased - and indirectly as a reduction in the demand for power also leads to lower electricity prices. 


\section{Methodology and key assumptions}

There are four main ways of reducing $\mathrm{CO}_{2}$ emissions in the electricity and heat sector:

\section{Putting a price on $\mathrm{CO}_{2}$}

The first is via a $\mathrm{CO}_{2}$ market (such as the EU Emissions Trading Scheme), where a cap is imposed on $\mathrm{CO}_{2}$ emissions. This leads to a price on quotas, thus increasing the costs for electricity producers using fossil fuels. As a consequence, the market price for electricity increases and thereby also the competitiveness of low carbon technologies. $\mathrm{CO}_{2}$ and energy taxes work in a similar way.

\section{Subsidies to renewables (or other low carbon technologies)}

Secondly, one can support renewable production directly, for example through certificate schemes, feed-in-tariffs (fixed electricity price) or feed-in premiums (a subsidy on top of the market price). In order to pay for the RE subsides, electricity consumers (or tax payers) pay an additional fee.

\section{Standards/norms}

Thirdly, standards or norms can establish limits for relative $\mathrm{CO}_{2}$ emissions, such as a maximum $\mathrm{g} \mathrm{CO}_{2} / \mathrm{kWh}$ for new or existing power plants. This could also involve bans on certain technologies or fuels, such as coal and nuclear power plants, which some countries may deem incompatible with their environmental objectives. If a certain technology/fuel is not compatible with long-term targets, standards or norms can prove to be an efficient way of regulation so as to avoid stranded investment costs.

\section{Energy efficiency}

Lastly, measures can be taken to reduce the demand for energy. Measures which increase the cost of generating electricity such as $\mathrm{CO}_{2}$ quotas and taxes will lead to higher electricity prices, which should stimulate electricity saving. 


\subsection{The EU ETS}

The EU ETS covers the majority of fossil fuel power plants in the EU, as well as energy intensive industry. The emission trading scheme is one of the most important EU tools to ensure compliance with the target of reducing $\mathrm{CO}_{2}$ emissions by $20 \%$ compared to 1990 . By 2020 , all companies encompassed by the EU ETS should on average reduce their emissions by $21 \%$ compared to 2005 . It has not yet been decided which target will apply in 2030.

When the $\mathrm{CO}_{2}$ caps are imposed on emissions from power and district heating plants in the Nordic countries and Germany, the model is able to compute the marginal costs of reducing $\mathrm{CO}_{2}$ emissions. This marginal cost can be interpreted as the price of $\mathrm{CO}_{2}$ allowances if the power and heat generators in the Nordic countries and Germany were the only participants in the EU ETS. In practice, the EU ETS $\mathrm{CO}_{2}$-price will be determined based on supply and demand from all companies under the ETS, including companies in other EU countries, companies from other sectors than power and heat and with the impact of imported credits from $\mathrm{CDM}$ projects. Hence, the $\mathrm{CO}_{2}$ prices resulting from the simulations should not be interpreted as a forecast of the $\mathrm{CO}_{2}$ prices within the EU ETS, but the dynamics within the EU ETS can be expected to resemble those modelled in the present study.

\subsection{4 policy scenarios for 2030}

14 policy scenarios are analysed regarding the development towards 2030 , with each focusing on a different combination of the abovementioned policies.

\section{Scenario 1. ETS cap ( $50 \%$ reduction)}

This scenario explores a situation where the EU ETS is the only climate regulation imposed. The $\mathrm{CO}_{2}$ reduction target achieved in the power sector is $50 \%$ compared to 2005 levels, which is in line with the objectives of the EU's "Roadmap for moving to a competitive low carbon economy in 2050" (EU Commission, 2011).

\section{Scenario 2. ETS cap and RE support}

The $2^{\text {nd }}$ scenario assumes the same $\mathrm{CO}_{2}$ reduction as scenario 1 , but in addition it assumes that all renewable energy technologies (hydro power exempted) receive support equal to $€ 20 / M W h$. This support could be provided via feed-in-premiums or through a certificate scheme. 


\section{Scenario 3. ETS cap, RE support and EE policy}

This scenario adds an energy efficiency target to scenario 2 . The energy efficiency target is modelled as $5 \%$ lower electricity demand than the two first scenarios. The cost of implementing the required energy efficiency policies is not analysed (nor included), but the simulation shows the impact on the supply side in terms of saved costs and altered generation.

\section{Scenario 4. ETS cap ( $40 \%$ reduction)}

The $4^{\text {th }}$ scenario is similar to scenario 1 , but in this case the $\mathrm{CO}_{2}$ reduction target is only $40 \%$.

\section{Scenario 5. ETS cap ( $30 \%$ reduction)}

This scenario is similar to scenario 1 , but in this case the $\mathrm{CO}_{2}$ reduction target is only $30 \%$.

\section{Scenario 6. ETS cap ( $50 \%$ reduction) and no investments in coal power}

The $6^{\text {th }}$ scenario is similar to scenario 1 , but in this situation it is assumed that no new investments are made in coal-fired capacity in any of the countries in the region. The ban on new coal-fired capacity could be the result of national energy policies, or a common EU agreement. This rationale is not specified.

\section{Scenario 7. ETS cap ( $30 \%$ reduction) and no investments in coal power}

This scenario builds on scenario 6, but in this case the reduction target is only $30 \%$. The underlying assumption is that EU countries are not able to agree on a strong target for the EU ETs (and/or the target is diluted by international $\mathrm{CO}_{2}$ credits etc.), but they maintain a ban against investments in the most polluting technologies, i.e. coal power.

Scenario 8. ETS cap ( $30 \%$ reduction), no investments in coal power and RE support

The $8^{\text {th }}$ scenario is similar to scenario 7 , but in addition to a ban on coal power, member states also support renewable energy technologies at $€ 20 / \mathrm{MWh}$.

\section{Scenario 9. ETS cap (50\% reduction) and lower natural gas price}

This scenario is similar to scenario 1 , but in this case a $20 \%$ lower natural gas price is applied. The lower price of gas could for example be a result of more shale gas developments in Europe than anticipated by the 
IEA. The scenario is utilised to measure the significance of this uncertainty on the power markets.

\section{Scenario 10. ETS cap (50\% reduction) and higher risk premium}

The $10^{\text {th }}$ scenario is similar to scenario 1 , but in this case it is assumed that the required rate on return is increased from $5 \%$ to $10 \%$ (real terms). Requiring a higher risk premium could be a response from investors to the significant level of uncertainties in the electricity market with respect to developments in future fuel prices, new technologies, and the policy framework (including future energy and climate policies).

\section{Scenario 11. ETS cap (50\% reduction) and no limit on investments in transmission capacity}

In scenario 1, limits were placed on the models ability to invest in transmission capacity. These were imposed in order to consider noneconomic barriers, such as environmental constraints and the required time to plan and build the interconnectors within the timeframe. In this scenario these constraints are relaxed, thus allowing the model to invest in as much transmission capacity as it deems economically attractive.

\section{Scenario 12. ETS cap (50\% reduction) and subsidies only to solar power and off-shore}

Scenario 12 explores a case where subsidies are only available for less mature (more costly) renewable technologies. A premium of €30/MWh for offshore wind power and solar power is included, whereas biomass based technologies (in a broad term) and onshore wind power, does not receive any subsidies.

\section{Scenario 13. ETS cap (50\% reduction), lower gas price, subsidy to renewable energy}

When a lower gas price is applied (sc. 9), this has a significant negative impact on the deployment of renewable energy because gas power becomes a more cost efficient $\mathrm{CO}_{2}$ reduction measure. Scenario 13 explores how subsidies to renewables of $€ 20 / \mathrm{MWh}$ would counteract this development.

\section{Scenario 14. ETS cap (60\% reduction)}

This case explores a situation where the $\mathrm{CO}_{2}$ reduction target is increased from $50 \%$ (sc.1) to $60 \%$. The EU ETS is the only regulation imposed to achieve the target. 


\begin{tabular}{llll} 
Table 4: Assumptions in the 14 different policy scenarios \\
Scenario & & \multicolumn{2}{c}{ Scenario assumptions } \\
& & & \\
& CO2 target & RE subsidy & Other changes \\
2013 & & RE targets & \\
2020 & & RE targets \\
1 & $50 \%$ & None & \\
2 & $50 \%$ & $€ 20 / M W h$ & \\
3 & $50 \%$ & $€ 20 / M W h$ & Lower elec. demand $(-5 \%)$ \\
4 & $40 \%$ & None & \\
5 & $30 \%$ & None & \\
6 & $50 \%$ & None & Ban on new coal power \\
7 & $30 \%$ & None & Ban on new coal power \\
8 & $30 \%$ & $€ 20 / M W h$ & Ban on new coal power \\
9 & $50 \%$ & None & Natural gas price reduced $20 \%$ \\
10 & $50 \%$ & None & $10 \%$ real interest rate \\
11 & $50 \%$ & None & No limit on trans. investment \\
12 & $50 \%$ & $€ 30 / M W h$ & Subsidy only to offshore/PV \\
13 & $50 \%$ & $€ 20 / M W h$ & Natural gas price reduced $20 \%$ \\
14 & $60 \%$ & None & \\
\hline
\end{tabular}

\subsection{Simulation tool}

The electricity market model Balmorel is utilised to simulate optimal dispatch and investments in power plants given input framework conditions and technology costs.

Balmorel is a least cost dispatch power system model. The model is based on a detailed technical representation of the existing power system; power and heat generation facilities as well as the most important bottlenecks in the overall transmission grid. The main result in this case is a least cost optimisation of the production pattern of all power units. It calculates generation, transmission and consumption of electricity and heat. Prices are generated from system marginal costs, emulating optimal competitive bidding and clearing of the market.

The model, which was originally developed with a focus on the countries in the Baltic region, is particularly strong in modelling combined heat and power production. In the current setup, the model includes the electricity and district heating systems of Denmark, Sweden, Norway, Finland and Germany.

\subsection{Investments in new generation capacity}

The model has a technology catalogue with a set of new power generation technologies that it can invest in according to the input data. The investment module allows the model to invest in a range of different 
technologies including (among others) coal power, gas power (combined cycle plants and gas engines), straw and wood based power plants, power plants with CCS and wind power (on and off-shore). Thermal power plants can be condensing units (produce only electricity) or combined heat and power plants. The model can, at a lower cost than building a new power station, convert an existing coal-fired plant to a plant fuelled by wood pellets or wood chips, or convert a natural gasfired plant to a biogas-fired plant. Wave power and solar power technologies are also included in the technology catalogue.

Investments in new generation technology are undertaken in a given year if the annual revenue requirement (ARR) in that year is satisfied by the market. A balanced risk and reward characteristic of the market is assumed, which means that the same ARR is applied to all technologies, specifically 0.08 , which is equivalent to $5 \%$ (approx. $7 \%$ in nominal terms) for 20 years. This rate reflects an investor's perspective.

In practice, this rate is contingent on the risks and rewards of the market, which may be different from technology to technology. For instance, unless there is a possibility to hedge the risk without too high a risk premium, capital intensive investments such as wind or nuclear power investments may be more risk intensive. This hedging could be achieved via, feed-in tariffs, power purchase agreements, and/or a competitive market for forwards/futures on electricity, etc.

In one of the scenarios we analyse the impact of increasing the required rate of return from $5 \%$ to $10 \%$.

\section{EU renewable energy targets for 2020}

Renewable energy development through to 2020 is projected along the lines outlined in the respective countries' National Renewable Energy Action Plans (NREAPs).

Table 5: Projected\% share of gross final electricity consumption as reported in the National Renewable Energy Action Plans, 2010

\begin{tabular}{lccc} 
Country & $\mathbf{2 0 1 0}$ & $\mathbf{2 0 1 5}$ & $\mathbf{2 0 2 0}$ \\
Denmark & $34.3 \%$ & $45.7 \%$ & $51.9 \%$ \\
Sweden & $54.9 \%$ & $58.9 \%$ & $62.9 \%$ \\
Finland & $26.0 \%$ & $27.0 \%$ & $33.0 \%$ \\
Germany & $17.4 \%$ & $26.8 \%$ & $38.6 \%$ \\
\hline
\end{tabular}

In Norway, the study considers the expected development towards 2020 in the common Swedish/Norwegian renewable energy certificate scheme. In Denmark, the study takes into account the decision to increase wind power generation so that it covers $50 \%$ of electricity demand in 2020. In practice, 
this means that Denmark will exceed the projected share of renewable energy in the electricity supply stated in its NREAP.

In German, a stronger renewables development in accordance with the German Energy Concept is included. This leads to a renewable energy share of approx. $45 \%$ by 2020 .

\section{New coal-fired power plants}

New coal-fired power plants are not considered to be politically acceptable in Sweden, Denmark or Norway. A separate scenario is made where this "ban" on coal-fired capacity is extended to Germany and Finland as well.

Considering the time horizon of the study, existing energy taxes and subsidy schemes are not included in the study.

\section{New nuclear power}

Within the study, a fixed development for nuclear power is assumed, as opposed to letting the model make the "optimal investments". The reason for this approach is twofold. First of all, the investment costs - and the cost of eventually decommissioning the plants - are associated with a high degree of uncertainty. Secondly, a number of environmental externalities are related to nuclear power, including the risk of nuclear accidents, radio-active emissions from mine-tailings, long-term storage of radioactive waste and the decommissioning of the power plants. These externalities are very difficult to monetize, and therefore decisions on nuclear power are based on both political assessments and financial calculations.

The nuclear development until 2030 is based on the following assumptions:

- Germany: Phase-out of nuclear by 2022 in accordance with announced plans.

- Sweden: Unchanged capacity.

- Finland: The Olkiluoto 3 is expected to come online by 2018 increasing the Finnish nuclear capacity from approx. 2700 MW today to $4300 \mathrm{MW}$ in the 2020 simulations. Two older units are expected to be decommissioned in 2027 and 2030 (Loviisa 1 and 2, total of 1 GW). Furthermore, two additional nuclear power plants are expected to go online between 2020 and 2030 with a capacity each of 1200 MW. As a result the total nuclear power capacity in Finland is expected to reach approximately 5,700 MW by 2030 . 


\subsection{Electricity demand}

Up till 2020, the demand for electricity is based on projections from the NREAPs. The development after 2020 is based on a BASREC study ${ }^{2}$ with input from participating countries. In accordance with existing plans, a reduction in electricity demand in Germany is expected, whereas electricity demand is fairly constant over the projection period in the Nordic countries.

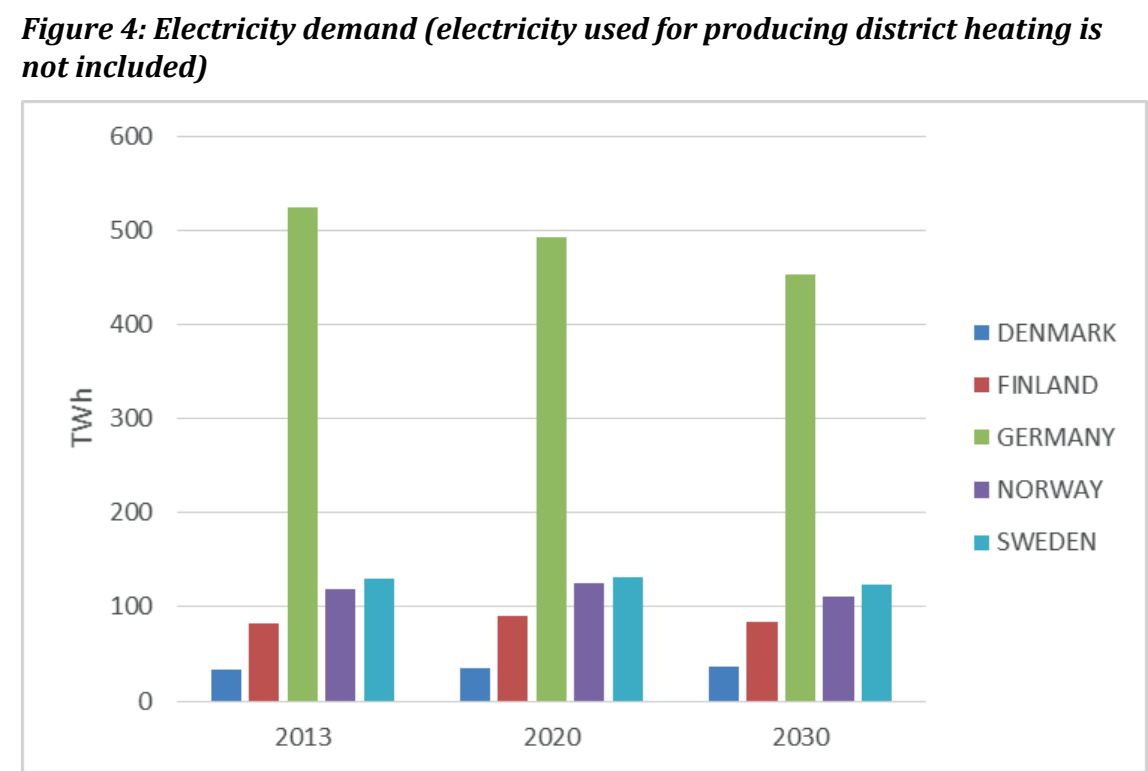

\subsection{Fuel prices}

Fossil fuel prices are based on the IEA World Energy Outlook 2012 New Policies Scenario, whereas the prices of different types of biomass are based on an analyses prepared for the Danish Energy Agency by Ea Energy Analyses.

In addition to the price of biomass, some local sources of biomass, such as agricultural residues, wood waste, and wood chips are constrained by their local availability, whereas only a market price is applied for wood pellets (i.e. no limitations on their use).

2 “Energy Policy Strategies of the Baltic Sea Region for the Post-Kyoto Period" (Ea Energy Analyses, 2012). 


\section{Results}

The following section presents and discusses the results from the model simulations. Due to the large amount of results, only Scenario 1 is presented in detail. Subsequently, the differences between the 10 scenarios are highlighted on a more aggregated level.

\subsection{Scenario 1}

Figure 5 compares electricity generation in 2013, 2020 and 2030 (scenario $1,50 \% \mathrm{CO}_{2}$ reduction). The scenario shows a development where the share of renewable energy ${ }^{3}$ increases gradually over the period from $39 \%$ in 2013 , to $57 \%$ in 2020 and $60 \%$ in 2030 . The most notable difference is an increase from wind power, solar and biomass generation, whereas coal power in particular, and to some extent nuclear power, is phased out.

Figure 5: Development electricity generation (TWh) 2010, 2020 and 2030 (Scenario 1) for the whole region (Denmark, Finland, Germany, Norway, Sweden)

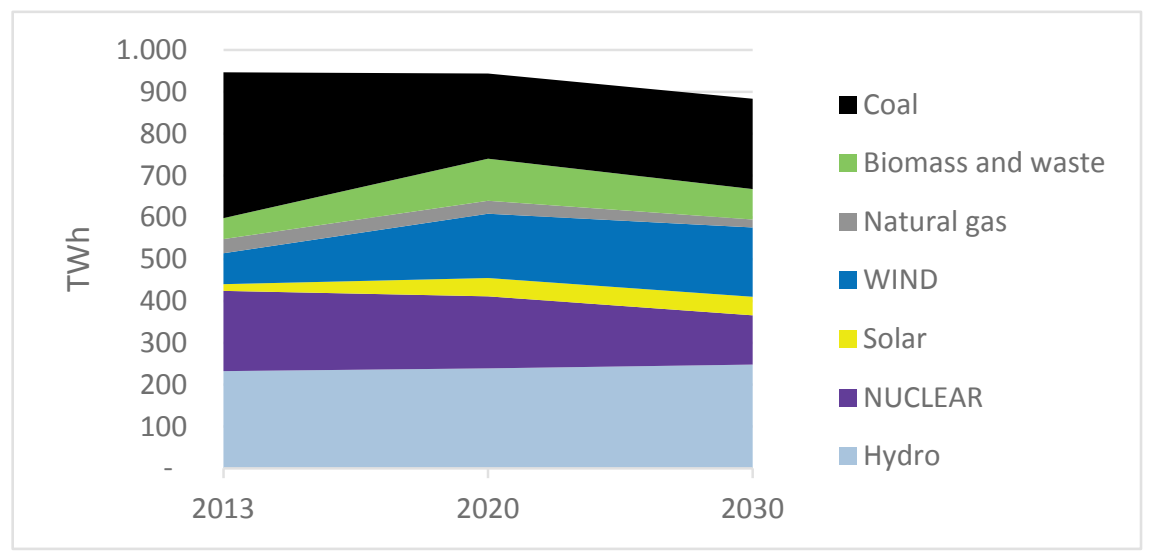

${ }^{3}$ Including electricity generation from waste incineration plants. 
Figure 6 provides an overview of electricity generation (TWh) for each country in 2030 grouped by fuel in scenario 1 . As depicted in the figure, the Nordic countries rely almost exclusively on renewable energy and nuclear power, whereas Germany still to a large extent bases its electricity generation on fossil fuels, in particular coal power.

Figure 6: Electricity generation (TWh) for each country in 2030 grouped by fuel in scenario 1

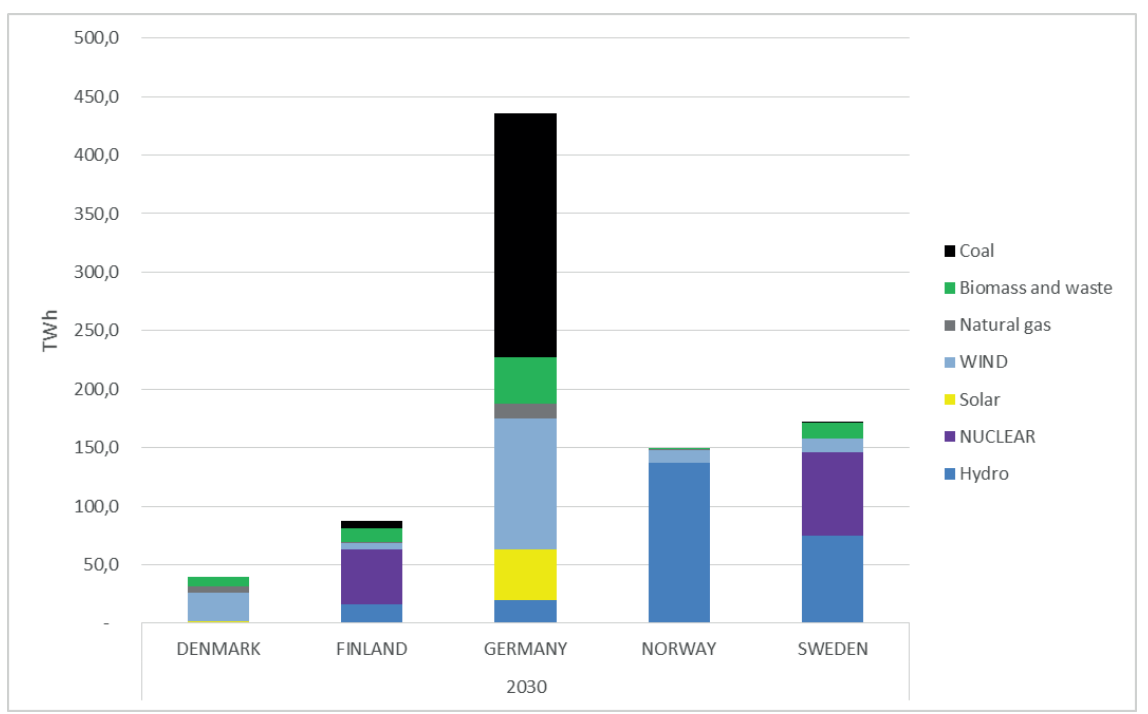

$\mathrm{CO}_{2}$ reductions are more profound in the Nordic countries $(61 \%$ reduction in 2030 compared to 2005) than in Germany (41\% reduction in 2030 compared to 2005), which indicate that the Nordic countries have access to cheaper $\mathrm{CO}_{2}$ mitigation options. ${ }^{4}$ This is due to the more abundant renewable resources (wind, biomass, hydro) as well as the access to cheap electricity storage from hydro power, which enables the costefficient integration of renewable energy.

Norway and Sweden are net exporters of electricity in $2030(+27$ and +30 TWh respectively), whereas Germany (-47 TWh), Denmark (-2 TWh) and Finland (-8 TWh) are net importers of electricity. The other policy scenarios show a similar pattern.

${ }^{4} \mathrm{CO}_{2}$ emissions from the incineration of the municipal solid waste are not included in the $50 \%$ reduction target for the region. 
The $\mathrm{CO}_{2}$ price in 2030 - i.e. the marginal cost of reducing $\mathrm{CO}_{2}$ emissions in the region - is roughly €20/tonne in scenario 1 .

Figure 7: Development in $\mathrm{CO}_{2}$ emissions (Mt) in each of the countries. 2030 is represented by scenario 1

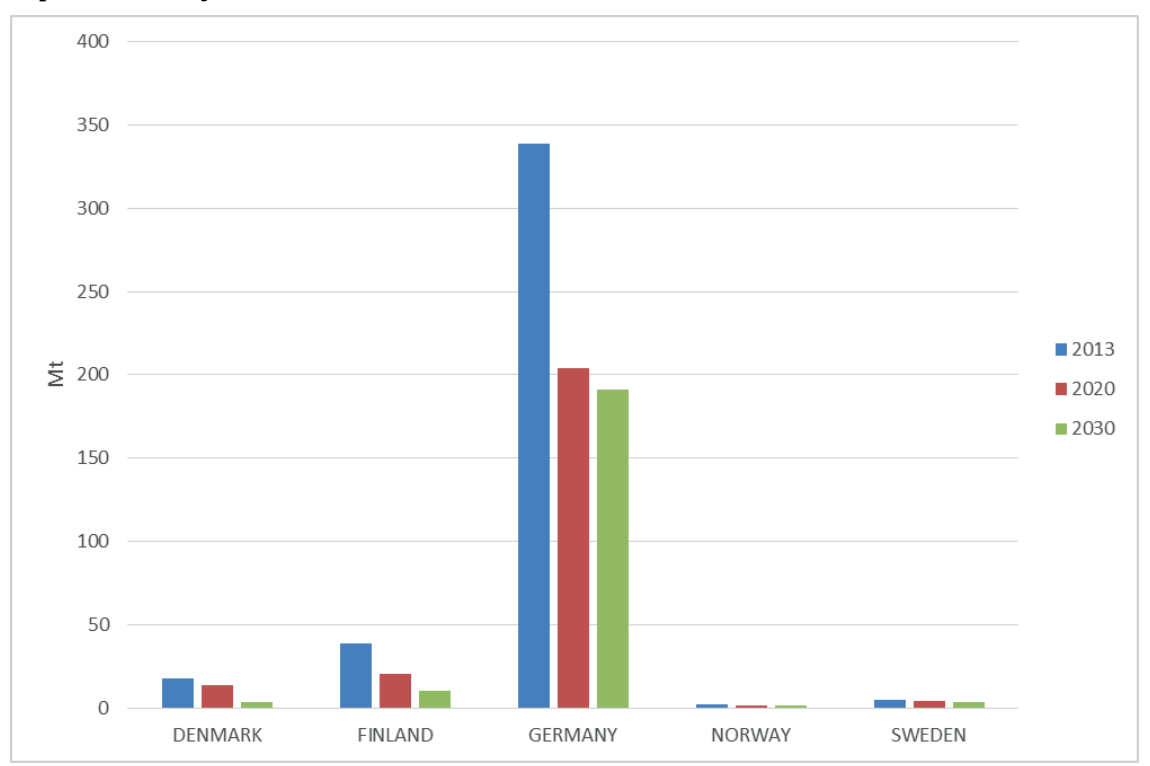

Average annual electricity market prices increase in Denmark and Germany from approx. €50/MWh in 2013, to just below €60/MWh in 2020, and just above $€ 60 / \mathrm{MWh}$ in 2030. Sweden, Norway and Finland see a different trend, with electricity prices decreasing from around $€ 45 / \mathrm{MWh}$ in 2013, to just above €40/MWh in 2020, and then rising to 2013 levels again in 2030. 


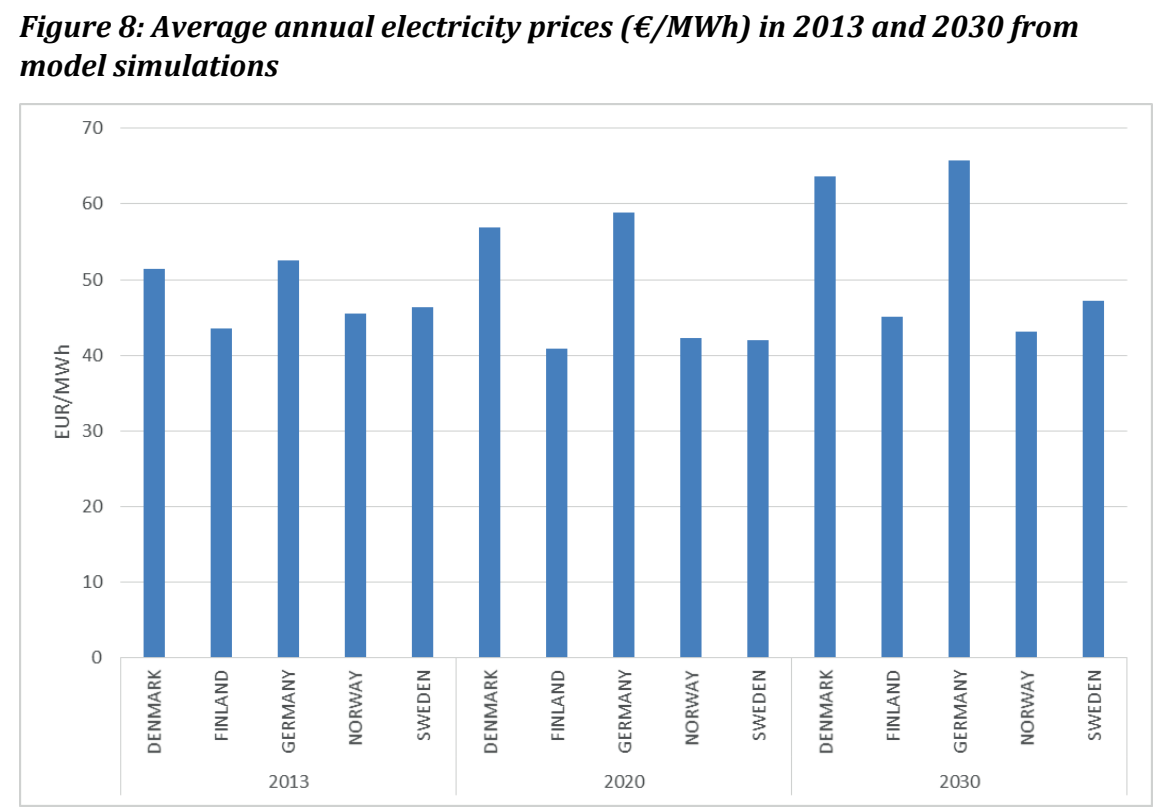

The electricity prices appear to be quite sensitive to the development of the grid in the region. The initial results from the project - presented at the AGFE seminar in Copenhagen in November 2013 - only included planned expansions of the transmission grid in the region. In this case, electricity prices in Norway dropped to around €25/MWh by 2030 . When new interconnectors are included as an investment option - as is the case in the current scenario - this helps reduce otherwise increasing price differences between the Nordic countries and Germany.

\subsection{Comparison of scenarios 1 to 14}

In all 14 policy scenarios, $\mathrm{CO}_{2}$ emissions are reduced in the modelled area and the share of renewable energy is increased between 2013 and 2030. There is also a very noticeable change in the supply mix towards 2020 as a result of the existing policies, the renewable energy targets, and the EU ETS.

\section{The role of renewables}

The highest share of renewable energy is achieved in scenario 8. The $\mathrm{CO}_{2}$ cap in this scenario is only $30 \%$, but the combination of a ban on new coal fired-power plants, and subsidies to renewable energy, leads to a rapid deployment of renewable energy (the share increases to 69\%). 


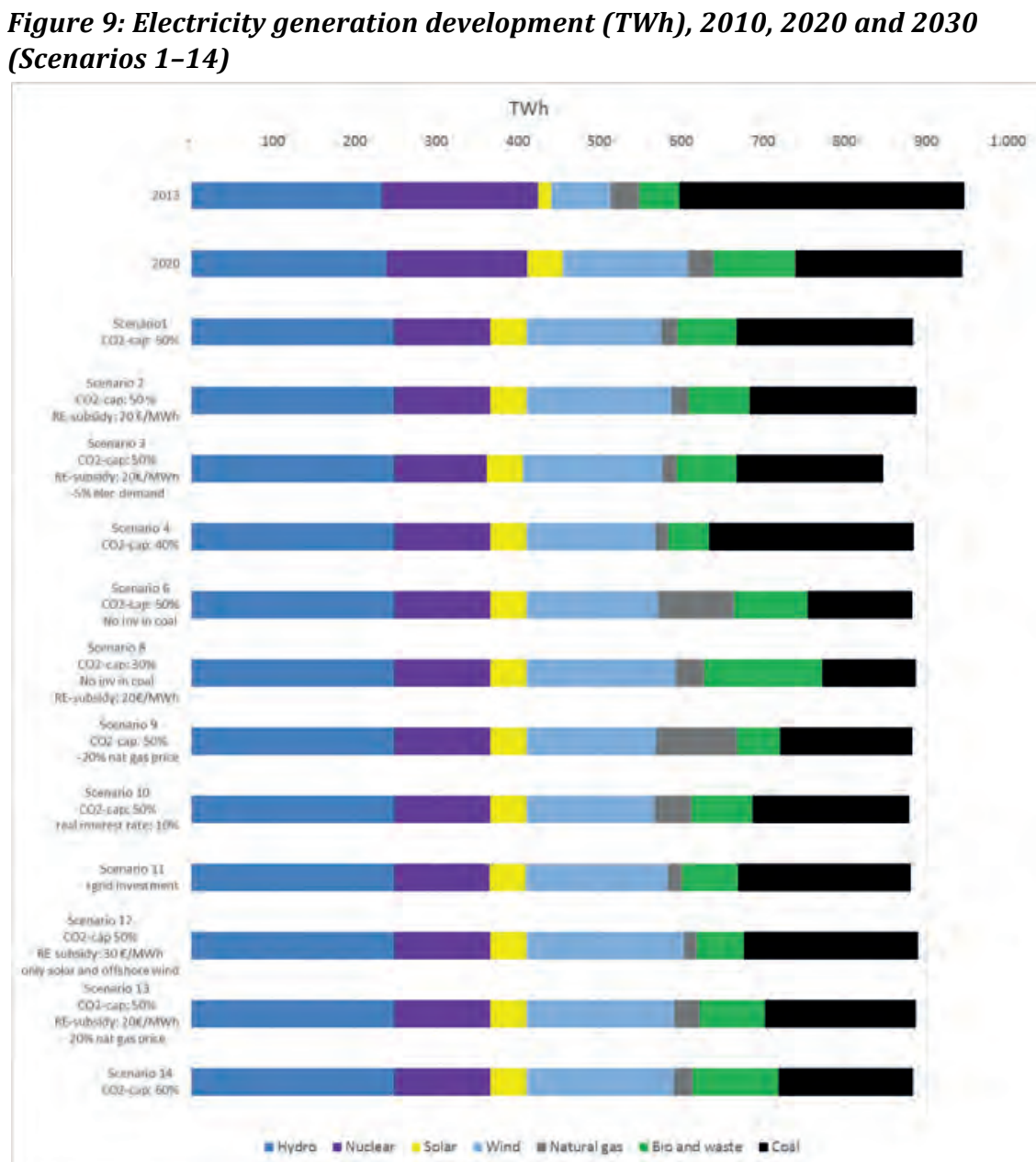

\section{The role of gas power}

In scenarios 1-5, the share of gas power in 2030 decreases compared to 2013 and 2020 levels. However, in scenario 9 where gas prices are $20 \%$ lower than forecasted by the IEA, the share of natural gas in electricity generation increases from $2 \%$ to $11 \%$. This indicates that gas and coal are in close competition, even though natural gas only plays a marginal role in scenarios $1-5$. The share of gas also increases markedly to $5 \%$ in scenario 10 due to the higher required rate of return $(10 \%$ vs. $5 \%$ real interest rate), as investors turn to technologies with lower capital costs.

Lastly, a higher gas share is seen in the three scenarios 6-8, where investments in new coal-fired capacity are not permitted. 
Figure 10: $\mathrm{CO}_{2}$ emissions in 2010, 2020 and 2030 (Scenarios 1-14)

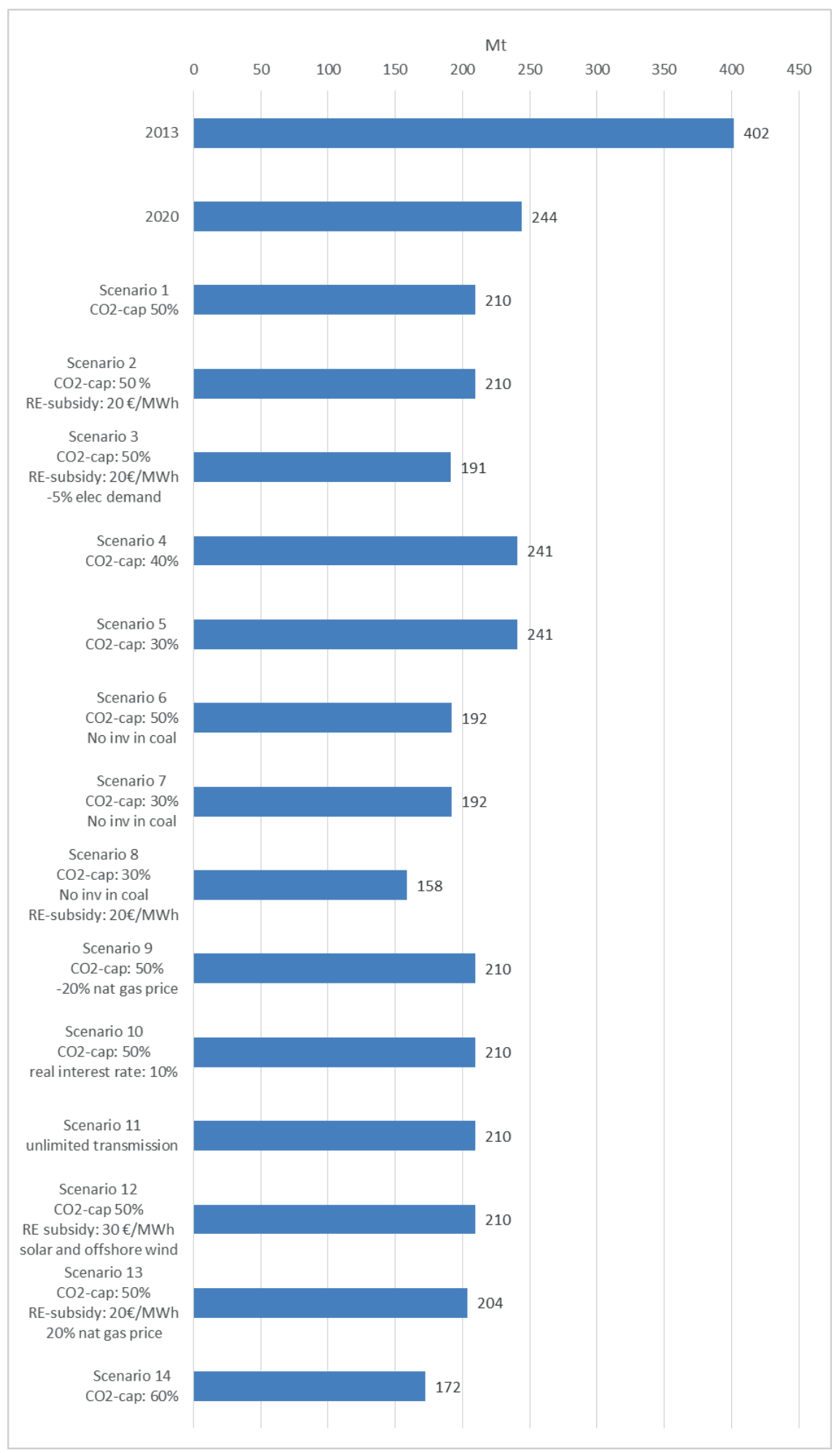




\section{$\mathrm{CO}_{2}$ emissions}

In several of the scenarios, the pre-defined caps on $\mathrm{CO}_{2}$ emissions are not binding. This is the case in scenarios 3 to 8 . In all six of these scenarios the $\mathrm{CO}_{2}$ emissions are lower than the specified cap, and therefore the resulting $\mathrm{CO}_{2}$ price is zero. Scenario 8 , which exhibits the highest share of renewable energy, also shows the lowest level of $\mathrm{CO}_{2}$ emissions. In fact, emissions are reduced by $64 \%$ compared to the 2005 level, which is far below the $30 \%$ cap in this scenario. It is also interesting to note that scenarios 4 and 5 become totally identical because their $\mathrm{CO}_{2}$ caps - which is the only parameter distinguishing them - is not a binding constraint in either of the two cases. The same is the case for scenarios 6 and 7 .

\section{$\mathrm{CO}_{2}$ prices}

The highest $\mathrm{CO}_{2}$ price is observed in scenario 14 (€36/tonne) where the $\mathrm{CO}_{2}$ reduction target is $60 \%$. Scenario 1 demonstrates a $\mathrm{CO}_{2}$ price of $€ 20 /$ tonne, and scenario 10 , where a higher discount rate is used, the price is $€ 21 /$ tonne. Renewable energy technologies are generally rather capital intensive compared to their fossil counterparts. This is the reason why the $\mathrm{CO}_{2}$ price is slightly higher in scenario 10 , where investor's required rate of return is increased to $10 \%$.

The $\mathrm{CO}_{2}$ price is less than $€ 1 /$ tonne in scenario 2 , where the renewable energy technologies are subsidised and therefore are closer to being competitive with gas and coal. The results show that the two tools $-\mathrm{CO}_{2}$ targets or subsidies for renewable energy - are highly complementary. This also means that in a situation such as scenario 2, where both EU ETS and RE subsidies are applied, the $\mathrm{CO}_{2}$ price does not represent the total marginal abatement cost of reducing $\mathrm{CO}_{2}$. Only if the EU Emission Trading Scheme (ETS) is the only $\mathrm{CO}_{2}$ reduction tool in place - as for example in scenario 1 - will the $\mathrm{CO}_{2}$ quota price reflect the total cost of reducing $\mathrm{CO}_{2}$ emissions.

A lower price for natural gas (scenario 9) also causes a lower $\mathrm{CO}_{2}$ price, because gas becomes more competitive with coal power. In a situation with tighter $\mathrm{CO}_{2}$ targets (beyond 2030), where the share of natural gas would also need to decrease, a lower gas price would have the opposite effect on the $\mathrm{CO}_{2}$ price.

In scenarios 3-8, the caps are not binding and consequently the price of $\mathrm{CO}_{2}$ becomes zero.

Figure 11 illustrates the $\mathrm{CO}_{2}$ prices in the various 2030 simulations (model output) with the $\mathrm{CO}_{2}$ reduction target applied and the different policies in place. 
Figure 11: $\mathrm{CO}_{2}$ prices 2030 (model output) compared to the $\mathrm{CO}_{2}$-reduction target applied and the different policies in place

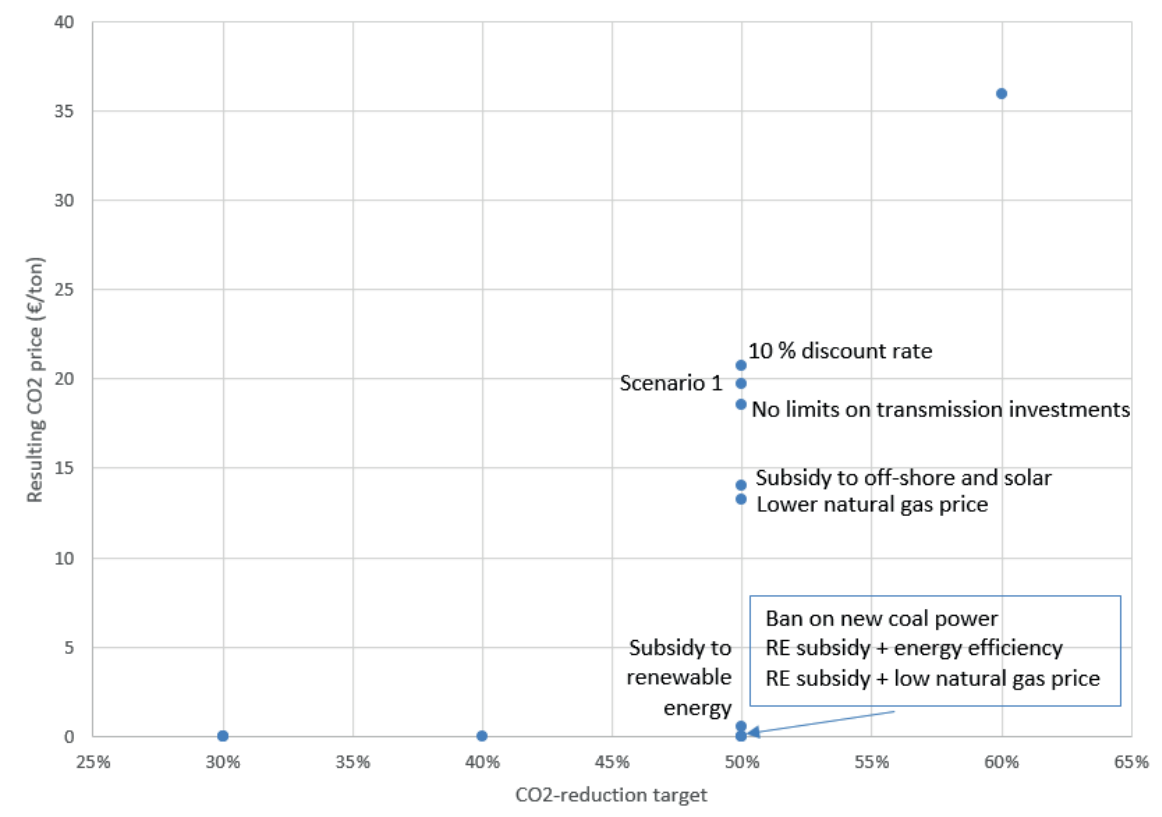

As previously mentioned the $\mathrm{CO}_{2}$ prices resulting from the simulations should not be interpreted as a forecast of the $\mathrm{CO}_{2}$ price within the EU ETS - since the modelling tool only considers power and district heating sector and because the geographical scope is limited to the Nordic countries and Germany - but the dynamics within the EU ETS can be expected to resemble those modelled in the present study.

\subsection{Impact of renewable energy sources on electricity prices}

In the scenarios where renewable energy subsidies are used, a significant downward impact on electricity market prices can be seen. The reason for this is two-fold: The renewable energy subsidies result in lower $\mathrm{CO}_{2}$ prices, thus leading to lower costs of fossil fuel based power production, and at the same time, they directly lower the price for renewable energy based electricity, because power plants that receive a subsidy will bid at a lower price in the spot market. 
Table 7: Impact of renewable energy subsidies on electricity market prices

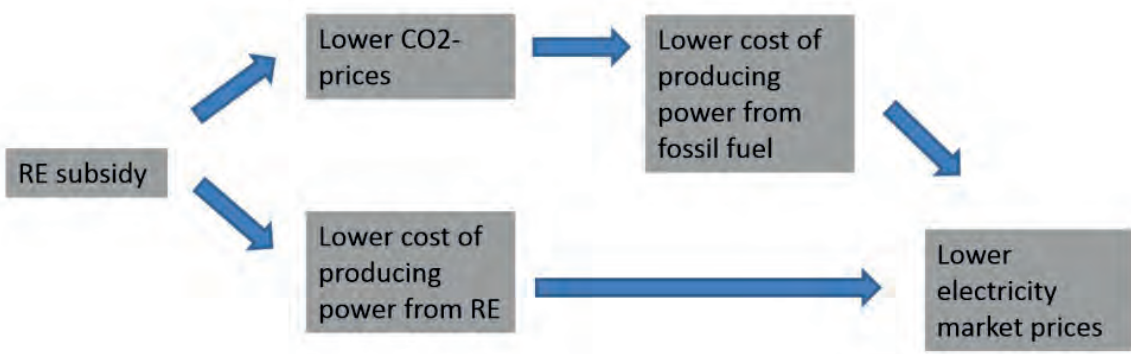

To the consumer electricity prices, the costs of RE subsidies should be added (assuming that the expansion with renewable energy is financed by the electricity consumers). In a situation with a market based RE certificate system or a feed-in-premium, the added cost to the consumer electricity price is the product of the subsidy and the share of renewable energy.

\subsection{Economic consequences}

In the model, the economics are distributed according to three major stakeholder groups:

- Producers of electricity and heat

a) + Revenues: Electricity sale, heat sales, RE subsidies

b) - Expenses: OPEX, CAPEX, $\mathrm{CO}_{2}$ quotas

- Consumers of electricity and heat

a) - Electricity, heat, RE subsidies

- Public (Government and TSO)

a) + Bottleneck income, $\mathrm{CO}_{2}$ quota revenue

b) - Grid costs

The sum of these figures expresses the total socio-economic benefit. Capital costs are computed on the basis of a $5 \%$ discount rate (in real terms).

The graph below compares the economics of scenarios 2 and 3 with scenario 1. Consumers benefit from the RE subsidies which are applied in scenario 1, whereas generators and the state realise higher costs. The reason for this is that the RE subsidies lead to lower electricity prices which directly benefits consumers. Consumers have to pay for the RE subsidies, but this cost is lower than the savings they realise from the lower electricity market price. It is assumed that the government obtains the revenue from the auctioning of $\mathrm{CO}_{2}$ quotas. Since the cost of $\mathrm{CO}_{2}$ quo- 
tas decrease in scenario 2 compared to scenario 1, this explains why state profits are reduced.

In total, the socioeconomic cost of scenario 2 is $€ 89$ million higher than in scenario 1 . This is the socioeconomic cost for the whole modelling area, which can be attributed to the introduction of RE subsidies compared to only having an ETS target.

Scenario 3 assumes a lower level of electricity demand compared to scenarios 1 and 2 . This development is assumed to take place as a result of active policies aimed at reducing the demand for electricity. (However, it can also be interpreted as the result of lower than anticipated economic growth resulting in a reduced demand for electricity). The simulations do not assume any additional costs related to these electricity savings, and therefore it is not surprising that the scenario demonstrates a good economy. The total socioeconomic benefit of the electricity savings in scenario 3 is app. $€ 2.1$ billion (comparing scenario 3 with scenario 2), but for consumers the benefit is even higher, at more than €14 billion, because consumers benefit from both lower electricity demand AND lower electricity prices.

Figure 12: Economic consequences (mill. $€$ ) of scenario 2 and 3 compared to scenario 1

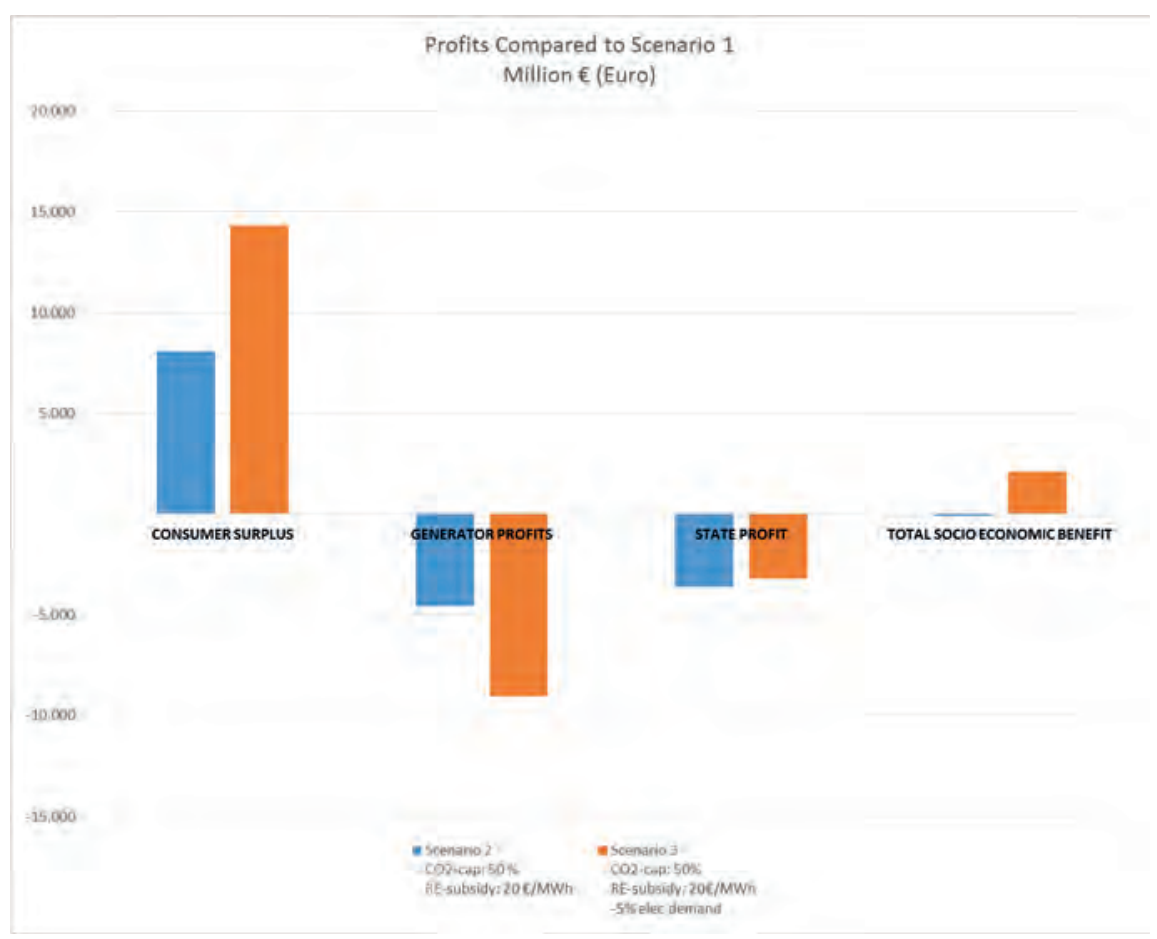


When the focus shifts to the distribution of benefits and costs between countries - i.e. summing the economics of producers, consumers and the public within each country - we see that Germany, Finland and Denmark will benefit from RE subsidies (scenario 2 compared to scenario 1) whereas Sweden and Norway will have their costs increased. The reason for this is that Germany, Finland and Denmark are net importers of electricity, and therefore will take advantage of lower electricity market prices - whereas the opposite is the case for Sweden and Norway. The economic comparison on the country level are displayed in Table 8.

Table 8: Economic comparison of scenario 2 (ETS target and RE subsidies) with scenario 1 (only ETS target) in millions of EUR-2013

\begin{tabular}{lrrrrrr} 
Mill. EUR-2013 & Denmark & Finland & Germany & Norway & Sweden & Total \\
Generator profits: & 173 & $-1,243$ & 1,790 & $-2,548$ & $-2,737$ & $-4,565$ \\
Consumer surplus: & -75 & 1,662 & 2,292 & 1,925 & 2,263 & 8,067 \\
TSO profit: & 69 & -66 & 205 & 135 & 87 & 429 \\
State profit: & -69 & -195 & $-3,661$ & -24 & -71 & $-4,020$ \\
Socio economic benefit: & 97 & 159 & 625 & -511 & -458 & -89 \\
\hline
\end{tabular}

Table 9 provides an overview of the total socioeconomic benefits for all stakeholders in the Nordics and Germany in scenario 2 compared to scenario 1.

Table 9: Economic comparison of scenarios 2-14 with scenario 1 (in millions of EUR-2013)

\begin{tabular}{|c|c|c|c|c|c|c|c|c|}
\hline \multirow{2}{*}{$\begin{array}{l}\text { Sce- } \\
\text { nario }\end{array}$} & \multicolumn{3}{|c|}{ Scenario assumptions } & \multirow{2}{*}{$\begin{array}{r}\text { Consu- } \\
\text { mer } \\
\text { Surplus }\end{array}$} & \multirow{2}{*}{$\begin{array}{r}\text { Genera- } \\
\text { tor } \\
\text { Profits }\end{array}$} & \multirow{2}{*}{$\begin{array}{l}\text { Public } \\
\text { Profit }\end{array}$} & \multirow{2}{*}{$\begin{array}{r}\text { Total } \\
\text { Socio } \\
\text { Econo- } \\
\text { mic } \\
\text { Benefit }\end{array}$} & \multirow{2}{*}{$\begin{array}{r}\text { Relative } \\
\text { cost* }\end{array}$} \\
\hline & $\begin{array}{r}\mathrm{CO} 2 \\
\text { target }\end{array}$ & RE subsidy & Other changes & & & & & \\
\hline 1 & $50 \%$ & None & & 0 & 0 & 0 & 0 & \\
\hline 2 & $50 \%$ & $€ 20 / M W h$ & & 8,067 & $-4,565$ & $-3,591$ & -89 & $0.15 \%$ \\
\hline 3 & $50 \%$ & $€ 20 / M W h$ & Lower elec. demand (-5\%) & 14,326 & $-9,047$ & $-3,166$ & 2,114 & $-3.59 \%$ \\
\hline 4 & $40 \%$ & None & & 11,202 & $-6,363$ & $-4,390$ & 449 & $-0.76 \%$ \\
\hline 5 & $30 \%$ & None & & 11,202 & $-6,363$ & $-4,390$ & 449 & $-0.76 \%$ \\
\hline 6 & $50 \%$ & None & Ban on new coal power & 2,951 & -757 & $-3,319$ & $-1,126$ & $1.91 \%$ \\
\hline 7 & $30 \%$ & None & Ban on new coal power & 2,951 & -757 & $-3,319$ & $-1,126$ & $1.91 \%$ \\
\hline 8 & $30 \%$ & $€ 20 / M W h$ & Ban on new coal power & 2,581 & $-1,741$ & $-3,082$ & $-2,243$ & $3.81 \%$ \\
\hline 9 & $50 \%$ & None & Nat.gas price reduced $20 \%$ & 4,858 & $-2,744$ & $-1,514$ & 600 & $-1.02 \%$ \\
\hline 10 & $50 \%$ & None & $10 \%$ real interest rate** & $-6,754$ & 5,616 & 1,020 & -117 & $0.20 \%$ \\
\hline 11 & $50 \%$ & None & No limit on trans. Investment & $-1,759$ & 2,647 & -659 & 229 & $-0.39 \%$ \\
\hline 12 & $50 \%$ & $€ 30 / M W h$ & Subsidy only to offshore/PV & 5,818 & $-6,564$ & 179 & -568 & $0.97 \%$ \\
\hline 13 & $50 \%$ & $€ 20 / M W h$ & Nat.gas price reduced $20 \%$ & 4,579 & -624 & $-3,761$ & 194 & $-0.33 \%$ \\
\hline 14 & $60 \%$ & None & & $-6,234$ & 2,295 & 2,948 & -990 & $1.68 \%$ \\
\hline
\end{tabular}

*The relative cost is calculated as the total socio-economic cost compared to the annual turnover of power and heat generators in the region (58.8€ billion).

In reviewing Table 9, the following observations are worth highlighting. 


\section{Scenarios}

Scenarios 4 and 5 (which ended up being identical) reduce total socioeconomic cost by approx. $€ 0.45$ billion due to the less stringent $\mathrm{CO}_{2}$ cap being applied.

Scenarios 6 and 7 (which also ended up being identical) result in increased total socioeconomic costs of approx. $€ 1.1$ billion. This is the consequence of not allowing new investments in coal-fired capacity. It should be noted that $\mathrm{CO}_{2}$ emissions are also reduced by an additional 18 Mt in these scenarios compared to scenario 1 . The cost of the additional $\mathrm{CO}_{2}$ reductions amount to $€ 63 /$ tonne.

Scenario 8 which combines a coal ban with RE subsidies, yields higher costs in the order of $€ 2.2$ billion, but this scenario also has the highest share of renewable energy, $69 \%$, and the lowest level of $\mathrm{CO}_{2}$ emissions (51 Mt lower than Scenario 1). The cost of the additional $\mathrm{CO}_{2}$ reductions (compared to scenario 1) amount to €44/tonne.

The 20\% lower natural gas price in scenario 9 leads to increases in the socioeconomic benefit of roughly $€ 0.60$ billion.

Scenario 13 builds on top of scenario 9, including a RE subsidy of $€ 20 / \mathrm{MWh}$. Adding the RE subsidy reduces the benefit from $€ 0.60$ billion to $€ 0.19$ billion. The socioeconomic cost is higher than in the case of adding a RE subsidy at "normal" gas prices, but a stronger impact of the subsidy is also seen in terms of more renewable energy generation.

Increasing the internal rate of return on investments from $5 \%$ to $10 \%$ in scenario 10 increases the total socioeconomic cost (based on a $5 \%$ discount rate) by roughly $€ 0.12$ billion.

When only the less mature (higher cost) renewable energy technologies are subsidised at $€ 30 / \mathrm{MWh}$ in scenario 11, the total socioeconomic cost is increased by $€ 0.57$ billion. This is considerably more than in scenario 2, where RE is supported uniformly at $€ 20 / \mathrm{MWh}$. At the same time, the share of RE is actually slightly lower in scenario 11 than in scenario 2 .

In scenario 14 the $\mathrm{CO}_{2}$ reduction target is increased to $60 \%$. This comes at a socioeconomic cost of roughly $€ 1$ billion. The average socioeconomic cost of the additional $\mathrm{CO}_{2}$ reductions (compared to scenario 1 ) is $€ 27 /$ tonne, whereas the marginal cost is $€ 36 /$ tonne.

Detailed economic consequences of scenarios 2-14 compared to scenario 1 is presented in the subsequent tables. 
Table 10: Detailed economic consequences of scenarios 2-10 compared to scenario 1 . Scenario 5 is identical with scenario 4 . Scenario 7 is identical with scenario 6

\begin{tabular}{|l|r|r|r|r|r|r|}
\hline SC2 & DENMARK & FINLAND & GERMANY & NORWAY & SWEDEN & TOTAL \\
\hline Generator profits: & 173 & -1243 & 1790 & -2548 & -2737 & -4565 \\
\hline Consumer surplus: & -75 & 1662 & 2292 & 1925 & 2263 & $\mathbf{8 0 6 7}$ \\
\hline TSO profit: & 69 & -66 & 205 & 135 & 87 & $\mathbf{4 2 9}$ \\
\hline State profit: & -69 & -195 & -3661 & -24 & -71 & $-\mathbf{4 0 2 0}$ \\
\hline Socio economic benefit: & 97 & 159 & 625 & -511 & -458 & $\mathbf{- 8 9}$ \\
\hline & & & & & & \\
\hline & & & & & & \\
\hline sc3 & DENMARK & FINLAND & GERMANY & NORWAY & SWEDEN & TOTAL \\
\hline Generator profits: & -38 & -2043 & 1331 & -3896 & -4401 & $-\mathbf{9 0 4 7}$ \\
\hline Consumer surplus: & 215 & 2695 & 4206 & 3283 & 3927 & $\mathbf{1 4 3 2 6}$ \\
\hline TSO profit: & 182 & -108 & 543 & 193 & 159 & $\mathbf{9 6 9}$ \\
\hline State profit: & -70 & -200 & -3766 & -24 & -73 & $-\mathbf{4 1 3 4}$ \\
\hline Socio economic benefit: & $\mathbf{2 8 9}$ & $\mathbf{3 4 4}$ & 2314 & -445 & $-\mathbf{3 8 9}$ & $\mathbf{2 1 1 4}$ \\
\hline
\end{tabular}

\begin{tabular}{|l|r|r|r|r|r|r|}
\hline SC4 & DENMARK & FINLAND & GERMANY & NORWAY & SWEDEN & TOTAL \\
\hline Generator profits: & -300 & -928 & -1367 & -1722 & -2047 & -6363 \\
\hline Consumer surplus: & 461 & 1280 & 6270 & 1426 & 1764 & $\mathbf{1 1 2 0 2}$ \\
\hline TSO profit: & -32 & -44 & -222 & -3 & 46 & $\mathbf{- 2 5 5}$ \\
\hline State profit: & -70 & -200 & -3766 & -24 & -73 & $-\mathbf{4 1 3 4}$ \\
\hline Socio economic benefit: & 59 & 107 & 916 & -323 & -310 & $\mathbf{4 4 9}$ \\
\hline
\end{tabular}

\begin{tabular}{|l|r|r|r|r|r|r|}
\hline Sc6 & DENMARK & FINLAND & GERMANY & NORWAY & SWEDEN & TOTAL \\
\hline Generator profits: & -199 & -707 & 3046 & -1334 & -1563 & $-\mathbf{7 5 7}$ \\
\hline Consumer surplus: & 216 & 1029 & -759 & 1094 & 1371 & $\mathbf{2 9 5 1}$ \\
\hline TSO profit: & 142 & -36 & 427 & 149 & 132 & $\mathbf{8 1 5}$ \\
\hline State profit: & -70 & -200 & -3766 & -24 & -73 & $-\mathbf{4 1 3 4}$ \\
\hline Socio economic benefit: & 89 & 86 & -1052 & -115 & -133 & $\mathbf{- 1 1 2 6}$ \\
\hline
\end{tabular}

\begin{tabular}{|l|r|r|r|r|r|r|}
\hline Sc8 & DENMARK & FINLAND & GERMANY & NORWAY & SWEDEN & TOTAL \\
\hline Generator profits: & 250 & -1211 & 4413 & -2515 & -2678 & $\mathbf{- 1 7 4 1}$ \\
\hline Consumer surplus: & -290 & 1632 & -2863 & 1893 & 2208 & $\mathbf{2 5 8 1}$ \\
\hline TSO profit: & 191 & -65 & 492 & 256 & 177 & $\mathbf{1 0 5 2}$ \\
\hline State profit: & -70 & -200 & -3766 & -24 & -73 & $-\mathbf{4 1 3 4}$ \\
\hline Socio economic benefit: & 81 & 156 & -1723 & -390 & -366 & $\mathbf{- 2 2 4 3}$ \\
\hline
\end{tabular}

\begin{tabular}{|l|r|r|r|r|r|r|}
\hline Sc9 & DENMARK & FINLAND & GERMANY & NORWAY & SWEDEN & TOTAL \\
\hline Generator profits: & -236 & -392 & -695 & -629 & -793 & $\mathbf{- 2 7 4 4}$ \\
\hline Consumer surplus: & 443 & 515 & 2563 & 549 & 787 & $\mathbf{4 8 5 8}$ \\
\hline TSO profit: & -18 & -26 & 24 & -48 & -91 & $-\mathbf{1 5 9}$ \\
\hline State profit: & 16 & -50 & -1300 & -1 & -21 & $\mathbf{- 1 3 5 6}$ \\
\hline Socio economic benefit: & 206 & 47 & 592 & -128 & -118 & $\mathbf{6 0 0}$ \\
\hline
\end{tabular}




\begin{tabular}{|l|r|r|r|r|r|r|}
\hline sc10 & DENMARK & FINLAND & GERMANY & NORWAY & SWEDEN & TOTAL \\
\hline Generator profits: & 323 & 196 & 4779 & 48 & 271 & $\mathbf{5 6 1 6}$ \\
\hline Consumer surplus: & -476 & -232 & -5676 & -75 & -296 & -6754 \\
\hline TSO profit: & 166 & -1 & 254 & 193 & 193 & $\mathbf{8 0 6}$ \\
\hline State profit: & 40 & 33 & 125 & 9 & 7 & $\mathbf{2 1 5}$ \\
\hline Socio economic benefit: & 52 & -3 & -518 & 175 & 176 & $\mathbf{- 1 1 7}$ \\
\hline
\end{tabular}

\begin{tabular}{|l|r|r|r|r|r|r|}
\hline sc11 & DENMARK & FINLAND & GERMANY & NORWAY & SWEDEN & TOTAL \\
\hline Generator profits: & -36 & 439 & -71 & 1115 & 1199 & $\mathbf{2 6 4 7}$ \\
\hline Consumer surplus: & 162 & -471 & 394 & -812 & -1032 & $\mathbf{- 1 7 5 9}$ \\
\hline TSO profit: & -145 & 28 & -25 & -182 & -91 & $-\mathbf{4 1 4}$ \\
\hline State profit: & -16 & 33 & -266 & 6 & -2 & $\mathbf{- 2 4 5}$ \\
\hline Socio economic benefit: & -35 & 30 & 33 & 128 & 74 & $\mathbf{2 2 9}$ \\
\hline
\end{tabular}

\begin{tabular}{|l|r|r|r|r|r|r|}
\hline sc12 & DENMARK & FINLAND & GERMANY & NORWAY & SWEDEN & TOTAL \\
\hline Generator profits: & -56 & -1519 & 1248 & -2883 & -3354 & -6564 \\
\hline Consumer surplus: & -530 & 1849 & -549 & 2359 & 2688 & $\mathbf{5 8 1 8}$ \\
\hline TSO profit: & 225 & -55 & 713 & 245 & 237 & $\mathbf{1 3 6 6}$ \\
\hline State profit: & -39 & -110 & -1005 & -10 & -23 & $\mathbf{- 1 1 8 8}$ \\
\hline Socio economic benefit: & -400 & 166 & 407 & -289 & -451 & $-\mathbf{5 6 8}$ \\
\hline
\end{tabular}

\begin{tabular}{|l|r|r|r|r|r|r|}
\hline sc13 & DENMARK & FINLAND & GERMANY & NORWAY & SWEDEN & TOTAL \\
\hline Generator profits: & 35 & -1057 & 1730 & 104 & -1437 & -624 \\
\hline Consumer surplus: & 147 & 1502 & 2601 & -678 & 1007 & $\mathbf{4 5 7 9}$ \\
\hline TSO profit: & 71 & -77 & 256 & 77 & 45 & $\mathbf{3 7 3}$ \\
\hline State profit: & -70 & -200 & -3766 & -24 & -73 & -4134 \\
\hline Socio economic benefit: & 184 & 167 & 821 & -521 & -458 & $\mathbf{1 9 4}$ \\
\hline
\end{tabular}

\begin{tabular}{|l|r|r|r|r|r|r|}
\hline sc14 & DENMARK & FINLAND & GERMANY & NORWAY & SWEDEN & TOTAL \\
\hline Generator profits: & 109 & 215 & 1489 & 128 & 355 & $\mathbf{2 2 9 5}$ \\
\hline Consumer surplus: & -266 & -381 & -5045 & -157 & -384 & $\mathbf{- 6 2 3 4}$ \\
\hline TSO profit: & 139 & 19 & 438 & 167 & 123 & $\mathbf{8 8 5}$ \\
\hline State profit: & 68 & 36 & 1894 & 16 & 49 & $\mathbf{2 0 6 3}$ \\
\hline Socio economic benefit: & 49 & -112 & -1224 & 154 & 142 & $\mathbf{- 9 9 0}$ \\
\hline
\end{tabular}




\section{Sammenfatning}

Den europeiske unionen har et mål om å redusere klimagassutslippene med 80-95 \% i 2050 i forhold til 1990. Veikartet for overgang til en konkurransedyktig lavkarbonøkonomi i 2050 utforsker ulike veier frem til 2050 som kan gjøre det mulig for EU å redusere klimagassreduksjoner på linje med 80-95 \% målet.

I 2007 kunngjorde EUs stats- og regjeringssjefer en serie av klima- og energimål som skal nås innen 2020, kjent som "20-20-20" mål.

For tiden diskuterer EU-lederne målene for 2030, inkludert hvorvidt 2020 rammeverk med separate mål for klimagassutslipp, fornybar energi og energieffektivisering bør videreføres. Håpet er at en avtale vil være på plass i god tid før en forventet global klimaavtale i 2015.

Denne studien analyserer effekten av ulike EU energi- og klimapolitiske tiltak på kraftmarkedene i Norden og Tyskland i 2030, og vurderer blant annet:

- Hvordan vil sammensetningen av elektrisitetsproduksjonen fremstå?

- Hva vil være andelen av fornybar energiproduksjon?

- Hvordan vil CO2-priser utvikle seg?

- Hva er implikasjonene for elektrisitetsproduksjon?

- Hvilke aktører vil dra nytte av ulike typer regulering, og hva er de samfunnsøkonomiske konsekvensene?

Analysene gjennomført dekker kraftsystemene i de nordiske landene og Tyskland, hvor elektrisitetsproduksjonen utgjør litt under 1000 TWh, eller nær $1 / 3$ av den totale kraftproduksjonen i EU-27.

Analysene viser at det er en svært høy grad av gjensidig avhengighet av ulike virkemidler som brukes for å oppnå klima- og energimål. Dersom subsidiene brukes til å støtte fornybare energiteknologier skal dette presse ned prisen på C02. Det samme er tilfelle dersom investeringer i ny kullkraft generasjon ikke er tillatt, eller hvis etterspørselen etter elektrisitet er redusert.

I tillegg, valg av politiske virkemidler har store virkninger på markedspriser for elektrisitet. Fornybare subsidier fører til betydelig lavere markedspriser. Implikasjonen av dette er også at prisene vi ser på spot- 
markedene ikke nødvendigvis viser den virkelige kostnaden ved å produsere strøm.

Alternative former for regulering, som for eksempel å sette et forbud mot etablering av særlige kraftverk, kan være et svært effektivt middel for å redusere CO2-utslippene, spesielt hvis det er kombinert med subsidier for fornybar energi. Men denne type regulering virker også å være mer kostbar.

En reduksjon i etterspørselen etter elektrisitet vil redusere kostnadene til forbrukerne direkte - mindre strøm må kjøpes - og indirekte, siden en reduksjon i etterspørselen etter strøm også fører til lavere strømpriser. 
Nordic Council of Ministers

Ved Stranden 18

DK-1061 Copenhagen K

www.norden.org

\section{Future EU energy and climate regulation}

In November 2013, the Renewable Energy Working Group (AGFE) of the Nordic Council of Ministers arranged a seminar in Copenhagen, Denmark, to explore renewable energy policy in the Nordic countries post 2030. A preliminary model analysis of future EU energy and climate regulation was prepared expressly for the seminar by Ea Energianalyse. This report describes the results from the model analysis. The results presented at the seminar in Copenhagen, and described in this report, have been supplemented with additional simulations on key parameters after discussions with the AGFE, and some of the assumptions have also been revised.

TemaNord 2014:570

ISBN 978-92-893-3892-9 (PRINT)

ISBN 978-92-893-3894-3 (PDF)

ISBN 978-92-893-3893-6 (EPUB)

ISSN 0908-6692

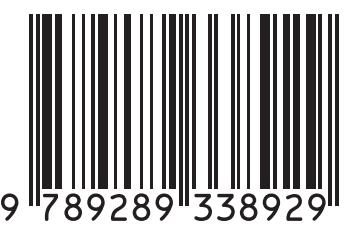

